\title{
Report on the Oregon Ballast Water Management Program in 2004
}




\section{Acknowledgements}

We would like to thank the Columbia Steamship Operators Association for providing support for preparation of this report. Jack Wylie, Sebastian Degens, Maurya Falkner, Charles Hanson, Robert Piorkowski, Rich Everett, Bivan Patnaik, Ian Davidson, and Scott Smith provided detailed comments and recommendations on specific sections of the report. Pam Meacham provided data form the Washington ballast water database. 


\title{
Report on the Oregon Ballast Water Management Program in 2004
}

\author{
Produced for the \\ Oregon State Legislature
}

By

The Oregon Ballast Water Task Force

\section{Prepared by}

Kiirsten Flynn and Mark Sytsma

Center for Lakes and Reservoirs

Portland State University

September 2004 


\section{Executive Summary}

The uptake and management of ballast water aboard ships is critical to safe cargo operations. Ballast water is taken up in one port to help stabilize a light or empty vessel, and is transported to another port and discharged as the vessel is loaded with cargo. Discharged ballast water includes aquatic nonindigenous organisms that can become established in the receiving water. Establishment of nonindigenous species often has detrimental impacts on native species and natural resources and can have severe economic consequences.

The commercial shipping industry is an important component of the Oregon economy. A sustainable economy requires effective and efficient management of pathways of invasive species introduction that are associated with shipping. To protect Oregon water resources from the risk of ballast water-related introductions the legislature enacted SB 895 during the 2001 session. The bill regulated ballast water discharge into Oregon waters. HB 3620 was enacted during the 2003 session and made minor changes to the ballast water management program. It also established a Task Force on Ballast Water Management to review the issues and make recommendations to the Legislature prior to the 2005 session.

This report to the Legislature provides information and analysis of the current state, regional, federal, and international ballast water regulations; shipping industry’s compliance with Oregon law; and ballast water treatment technology. Recommendations are made for improvement of the Oregon ballast water program based on this review and analysis.

The Washington Department of Fish and Wildlife (WDFW) provided the data to assess compliance with Oregon law. Compliance was very low in 2003/2004; 60 percent of ships calling on Oregon ports either failed to report (29 percent), submitted incomplete reports (30 percent), or submitted late reports (one percent). Compliance was much lower than in 2002 
(98.5 percent), but is consistent with a correlation between staffing levels and compliance reported previously in Oregon and in Washington. A decline in staffing leads to a decline in compliance (Vinograd and Sytsma, 2002). During the past two years the Oregon ballast water program has not been effectively staffed.

Substantial changes have occurred in international, federal, and neighboring state ballast water management programs during the past two years. The U.S. Coast Guard has implemented new rules, amendment of the California ballast water law has been proposed, and The International Convention for the Control and Management of Ships Ballast Water and Sediments was adopted by consensus by the International Maritime Organization (IMO). The IMO convention has yet to be approved by Congress or ratified. The ballast water regulatory changes that have occurred necessitate changes in Oregon regulations to ensure compatibility with new federal regulations, proposed regulations in California, and existing Washington regulations.

Although recognized as inefficient and having some safety constraints, ballast water exchange is still the primary treatment method for ballast water prior to discharge. Alternatives to exchange, e.g., deoxygenation, UV light, and ozone, are under investigation but not yet proven practical for ship-scale applications. The U.S. Coast Guard is investigating discharge standards, however, a federal discharge standard has not been established. A discharge standard was included in the IMO Convention. Neighboring states and the federal government have incentive programs for ballast water treatment testing, but only two systems in Washington have been approved. Oregon law only allows the discharge of ballast water treated in a manner approved of by the U.S. Coast Guard, which creates potential problems for vessels with Washingtonapproved treatment technology that visit both Washington and Oregon ports on the Columbia River. 
Based on these findings and others, the Oregon Ballast Water Task Force makes the

following recommendations:

\section{Shipping Compliance}

- While new U.S. Coast Guard regulations and a grant-funded, ballast water management database project at Portland State University may increase compliance with reporting, enforcement of Oregon law requires state support. A 0.5 FTE position at DEQ for enforcement and coordination with neighboring states is needed to protect Oregon water resources.

- Definitions of coastal and open-sea exchange in Oregon law should be amended to include the U. S. Coast Guard definitions of exchange using flow-through or emptyrefill. Such an amendment would prohibit discharge of partially exchanged ballast water.

- Oregon should monitor and participate in federal discharge standard development to ensure that they are protective of Oregon water resources.

- Outreach to the maritime industry in Oregon should be initiated to increase compliance.

\section{Efficacy of Ballast Water Exchange}

- Oregon should optimize use of exchange for management of aquatic introduced species in coastal shipping, and facilitate a regionally consistent approach, by amending the coastal exchange definition to require exchange at greater than $50 \mathrm{NM}$ off shore and greater than $200 \mathrm{~m}$ depth.

\section{Compatibility with Federal Laws and Regional Programs}

- Oregon law should be amended to:

o delete the $2000 \mathrm{~m}$ depth requirement for open sea exchange to maintain compatibility with USCG requirements;

o replace the current latitude definition with a 50 NM distance and $200 \mathrm{~m}$ depth criteria for coastal exchange;

0 include a requirement that ships maintain a ballast water management log and plan; and,

o modify reporting requirements to match the U.S. Coast Guard requirements for reporting on voyages less than 24 hours long and include a definition of "port or place".

\section{Research Requirements for Management of ANS Introductions}

- The State should invest in ballast water management technology and development by creating a center of expertise on engineering, economics, ecology, and biology of ANS management in ballast water and shipping. Such an investment would place 
Oregon at the forefront of a developing, “green” industry servicing ANS prevention in the shipping industry.

- Additional resources are required for DEQ to enhance and improve integration of ballast water management with other efforts managing invasive species in Oregon.

\section{Other Considerations}

- Articulated tug and barge (ATB) and integrated tug and barge (ITB) are required to report ballast water management operations to the U.S. Coast Guard and may be considered self-propelled vessels under Oregon law. Outreach and consultation with ocean-going and river barge operators is required to clarify ballast water management operations and reporting requirements.

- Although reporting compliance may increase with new U.S. Coast Guard regulations and with a new regional ballast water database project at PSU, lack of funding for enforcement of the Oregon ballast water program limits its efficacy. General funds, grant funds, or a per ship fee of $\$ 50$ are required to fund enforcement of ballast water management laws in Oregon.

- The Ballast Water Task Force should be extended through 2006 and be charged with updating the 2007 Legislature on policy and science relating to ANS and shipping.

- The preponderance of shipping traffic on the Columbia is from ports on the west coast, and consistency in ballast water management among states is required for efficient shipping and effective protection against aquatic bioinvasions. Oregon should continue to search for ways to integrate the State program with neighboring state and federal ballast water management programs. 


\section{Table of Contents}

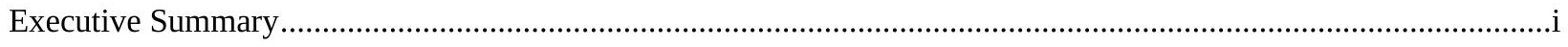

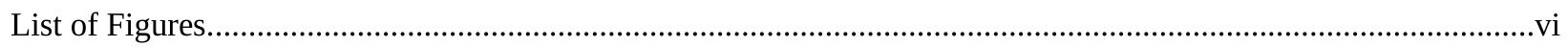

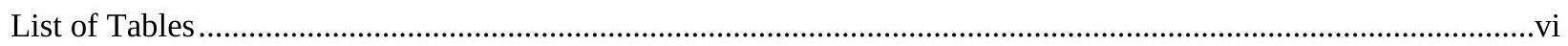

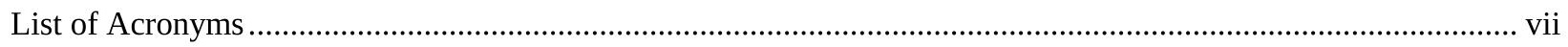

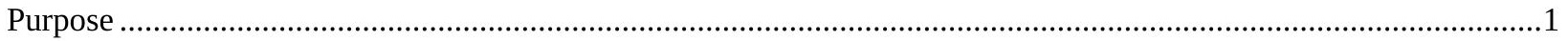

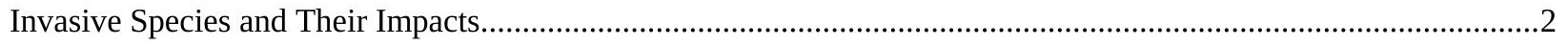

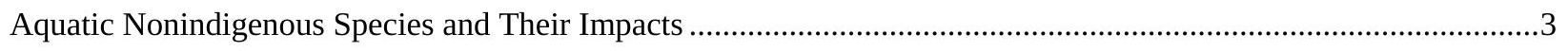

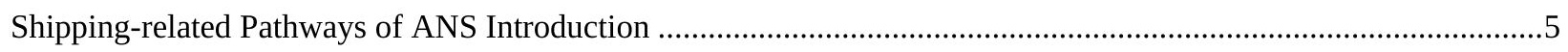

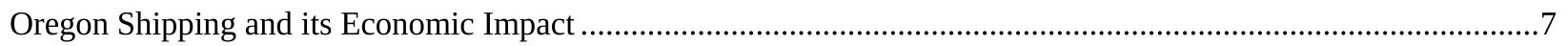

Oregon Ballast Water Regulation Compliance...............................................................................................11

Other Ship Mediated Vectors of ANS: Hull Fouling, Sea Chests and Anchor Chains ..........................................18

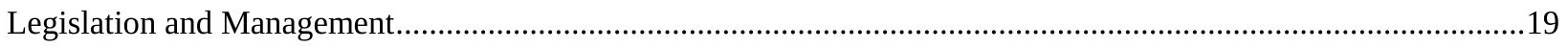

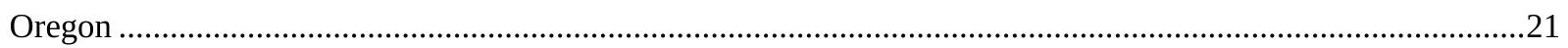

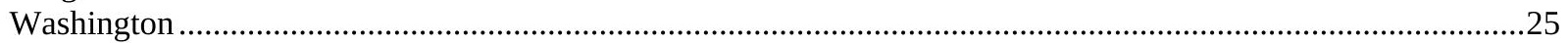

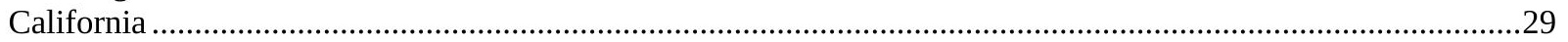

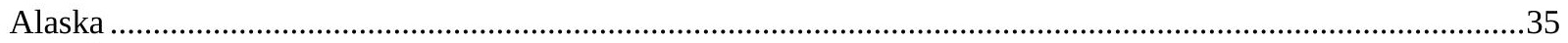

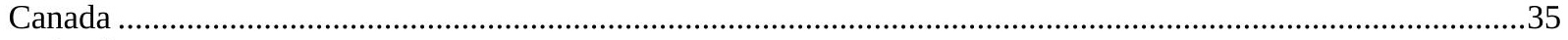

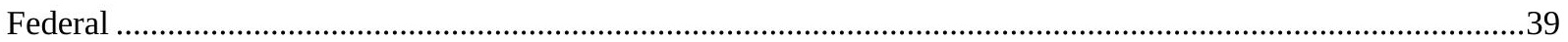

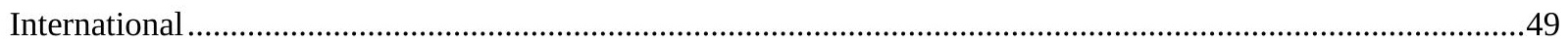

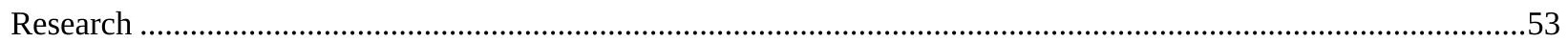

Biology of Ballast Water Communities and the Ecology of Invasions.................................................................53

Ballast Water Exchange and Development of Treatment Technology ……...........................................................55

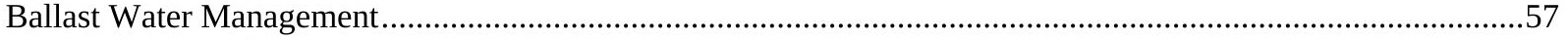

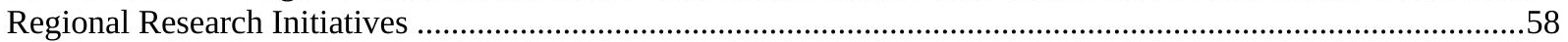

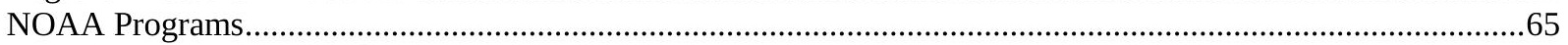

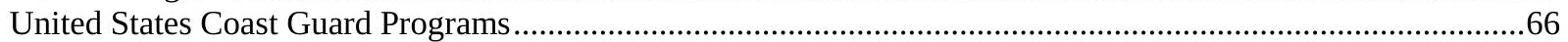

United States Environment Protection Agency Programs ...................................................................................66

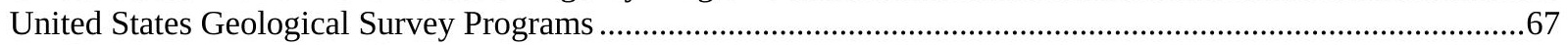

Smithsonian Environmental Research Center (SERC) …….............................................................................67

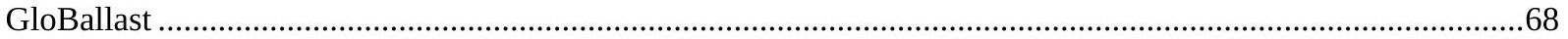

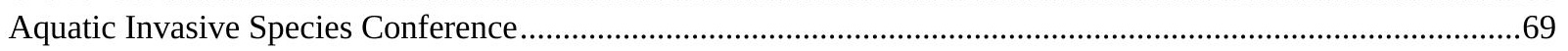

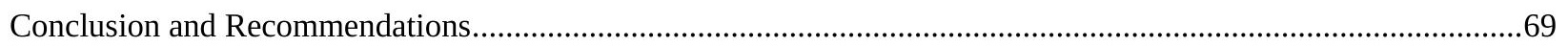

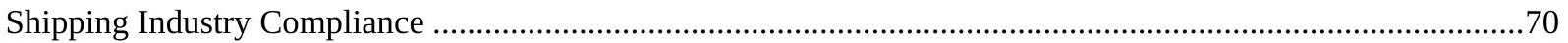

Ballast Water Treatment Technologies and Standards for Ballast Water Discharge ..............................................71

Efficacy of Ballast Water Exchange ..................................................................................................................

Compatibility with Federal Laws and Regional Programs .................................................................................72

Research Requirements for Management of ANS Introductions .........................................................................74

Ballast Water Management and Oregon Invasive Species Management.............................................................74

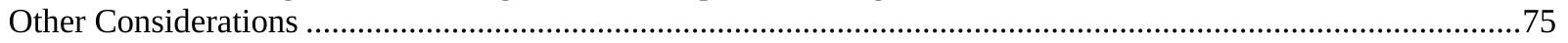

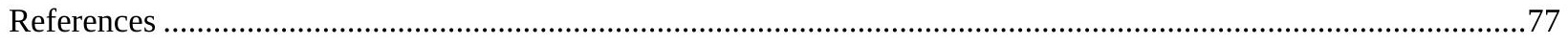

Appendix A. Ballast Water Task Force Advisors, Members and Staff Support........................................................85

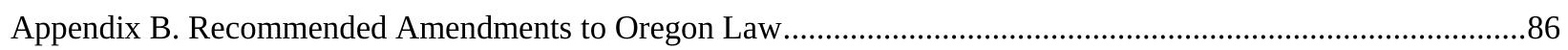




\section{List of Figures}

Figure 1. Accumulation of ANS in the lower Columbia River over time (Blue squares represent invertebrates, green circles represent fish, Sytsma, unpublished data).........................................................................................

Figure 2. Pathways of introduction of invertebrates into the lower Columbia River (Sytsma, unpublished data), ....... 4 Figure 3. Vessel types stopping at Oregon and Columbia River Ports (01/01/03 to 06/30/04). (Data source: WDFW ballast water database.) .

Figure 4. Last port of call for vessels entering Oregon ports (07/01/03 to 06/31/04). (Classified vessels are military vessels. Data source: WDFW ballast water database.).....................................................................................10

Figure 5. Distribution of last port of call for transoceanic voyages to Oregon ports (07/03 to 07/04). (Classified are vessels are military vessels. Data source: WDFW ballast water database.) .....................................................10

Figure 6. Distribution of last port of call for vessels traveling coastally (07/01/03 to 06/30/04). (Data source: WDFW ballast water database.)

Figure 7. Reporting compliance for vessels entering Oregon ports between 07/01/03 to 06/30/04. (Data source: WDFW ballast water database.) .....................................................................................................................12

Figure 8. Breakdown of origin of discharged unexchanged ballast water in Oregon waters 11/03 to 03/31/04. (Data

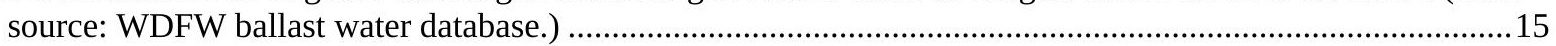

Figure 9. Volume of ballast water discharged into Oregon waters following flow-through, empty-refill, and no exchange, 11/01/03 to 03/31/04. (Data source: WDFW ballast water database.) …………………....................16

Figure 10. California ports reported as last port of call for ships calling on Columbia River ports (Other = Avon, Alameda, Ensenada and Eureka. Data source: WDFW ballast water database). ..............................................17

Figure 11. Schematic of the Oregon coastal ballast water exchange requirement (Source: Vinograd and Sytsma, 2002)

Figure 12. Reporting compliance for Washington and Oregon Ports from May 2002 to March 2004 (data from WDFW ballast water reporting database) .

\section{List of Tables}

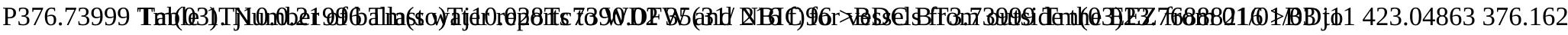
12/31/03. (Data sour44r4 .30 1072.3561 Tm( ves)Tj10(t)Tj10.02 00.738020 ve996 Tm(31/)Tj10.02 8.00.02 312.23112 376P1 


\section{List of Acronyms}

AAC: Alaska Administrative Code

AIRD: Aquatic Invasion Research Directory

ANS: Aquatic Nuisance Species

ATB: Articulated Tug and Barge

BMP: Best Management Practices

BOE: Board of Equalization

BW: Ballast Water

BWM: Ballast Water Management

BWE: Ballast Water Exchange

BWT: Ballast Water Treatment

CDOM: Color Dissolved Organic Matter

CFR: Code of Federal Regulations

CLR: Center for Lakes and Reservoirs (Portland State University, Oregon)

CMAC: Canadian Maritime Advisory Committees

COTP: Captain Of The Port

CRANSI: Columbia River Aquatic Nuisance Species Initiative

CRSOA: Columbia River Steamship Operators Association

CSA: Canada Shipping Act

CSLC: California State Lands Commission

DEQ: Department of Environmental Quality (Oregon)

DFG: Department of Fish and Game (California)

DHS: Department of Homeland Security (Federal)

DOT: Department of Transportation (Federal)

EEZ: Exclusive Economic Zone

EPA: Environmental Protection Agency (U.S.)

EPW: Environment and Public Works

ETV: Environmental Technology Verification

FR: Federal Regulations

GEF: Global Environment Facility

GISP: Global Invasive Species Programme

GloBallast: Global Ballast Water Management Programme

GRT: Gross Registered Tonnage

HB: House Bill (Oregon)

HR: House of Representative's Bill (United States)

IMO: International Maritime Organization

ISSG: Invasive Species Specialist Group

ITC: International Tonnage Certificate

LCRANS: Lower Columbia River Aquatic Nuisance Survey

MARAD: Maritime Administration

MEPC: Marine Environmental Protection Committee (IMO)

MCTS: Marine Communications and Traffic Services (Canada)

NANPCA: Nonindigenous Aquatic Nuisance Prevention and Control Act (1990)

NBIC: National Ballast Information Clearinghouse

NEMW: Northeast Midwest Institute

NISA: National Invasive Species Act 
NM: Nautical Mile

NOAA: National Oceanic and Atmospheric Administration

NRC: National Research Council

OAL: Office of Administrative Law (California)

PEA: Programmatic Environmental Assessment

PEIS: Programmatic Environmental Impact Statement

PSMFC: Pacific States Marine Fisheries Commission

PSU: Portland State University

ppt: Parts Per Thousand

PRC: Public Resources Code (California)

RCW: Revised Code of Washington

R\&D: Research and Development

Ro/Ro: Roll on Roll off vessel (carries vehicles of all types)

SB: Senate Bill (Oregon)

SERC: Smithsonian Environmental Research Center

SSB: Substitute Senate Bill

SWRCB: State Water Resources Control Board (California)

TAG: Technical Advisory Group (California)

TBT: Tributyltin

TCMS: Transport Canada Marine Safety

TEU: Twenty foot Equivalent Units

T \& I: Transportation and Infrastructure

TSS: Total Suspended Solids

UNDP: United Nations Development Programme

USCG: United States Coast Guard

USFWS: United States Fish and Wildlife Service

USGS: United States Geological Survey

WDFW: Washington Department of Fish and Wildlife 


\title{
Report on the \\ Oregon Ballast Water Management Program in 2004
}

\author{
Kiirsten Flynn and Mark Sytsma \\ Center for Lakes and Reservoirs \\ Portland State University
}

\section{Purpose}

This report was prepared for the Oregon legislature pursuant to HB 3620, which was passed during the 2003 session of the Oregon legislature to address management of ballast water discharged from ships. HB 3620 amended and created new provisions in ORS 783.625, 783.630, 783.635, and 783.640. The bill removed sediment from the definition of ballast water, allowed discharge of treated ballast water, created a task force on ballast water management, and required this report.

In HB 3620, the legislature charged the task force to study and make recommendations on changes to ORS 783.630 to 783.640 , including but not limited to the following considerations:

- $\quad$ Shipping industry compliance with ORS 783.630 to 783.640;

- Practical and cost-effective ballast water treatment technologies;

- Appropriate standards for discharge of treated ballast water into Oregon waters;

- The degree to which open sea and coastal ballast water exchange reduces risk of introduction of nonindigenous species into Oregon waters;

- The compatibility of 783.630 to 783.640 to federal laws and regulations and to ballast water management programs established by the states of Alaska, California, Washington, and the Province of British Columbia;

- Research requirements for better management of nonindigenous species introduction via ballast water; and

- The degree to which ballast water management is consistent with and made part of efforts to eradicate invasive species throughout Oregon. 


\section{Invasive Species and Their Impacts}

Invasive, nonindigenous species (INS) (aquatic and terrestrial) impact our life and all regions and habitats of the United States and every nation in the world (National Invasive Species Council, 2001). Estimated economic damage associated with INS, including control measures, are approximately \$138 billion a year (Pimentel et al., 2000). In the Great Lakes, \$3 billion has been spent in the past 10 years to mitigate damage caused by zebra mussels (Dreissenia polymorpha) alone (H.R. 5396), and impacts on industries, business and communities amounting to over \$5 billion (New York Sea Grant, 1994). The rate of new introductions is increasing (Figure 1) (see also Cohen and Carlton 1998, Carlton, 2001, Ruiz and Carlton, 2003), which suggests that economic impacts are increasing as well.

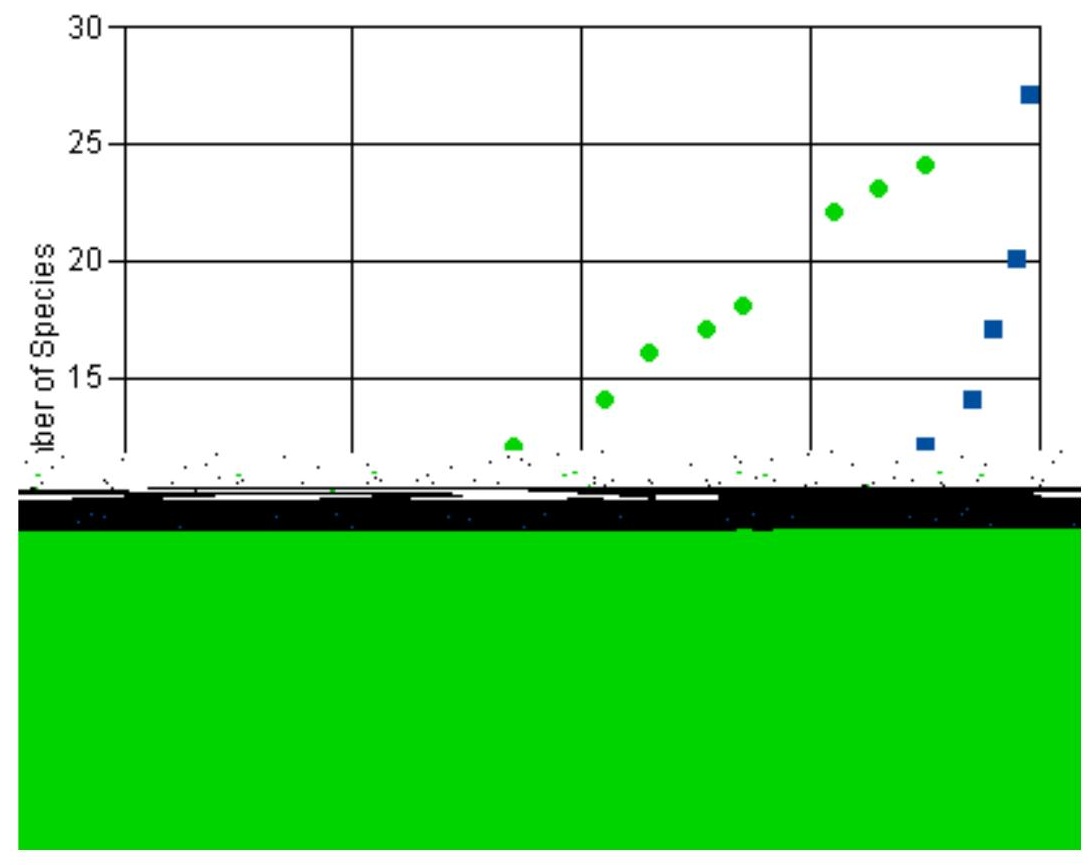

Figure 1. Accumulation of ANS in the lower Columbia River over time. Blue squares represent invertebrates; green circles represent fish, (Sytsma, unpublished data).

The establishment of INS in the Pacific Northwest threatens valuable natural resources.

Coastal estuaries in the Pacific Northwest provide critical habitat for shellfish production and commercial fisheries, both of which are major contributors to the coastal economy: 
abundant in the lower Columbia and Snake Rivers. The Siberian prawn (Exopalaemon modestus) occurs in high densities and introduced copepods (Psuedodiaptomus spp) can dominate the river’s zooplankton community (Sytsma, unpublished data).

Shipping related pathways of introduction, especially ballast water, account for the majority of ANS in the lower Columbia River (Figure 2), although other pathways are also important. The Zebra mussels, Dreissenia polymorpha was a ballast water introduction into the Great Lakes, but will most likely be introduced to Oregon on recreational boats trailered to Oregon from infested waters in the Midwest. Green crabs (Carcinus maenus) were probably introduced to California waters via contaminated bait or seafood from the East Coast, and have subsequently spread to Oregon estuaries on ocean currents. Similarly, smooth cordgrass (Spartina alterniflora) was introduced into Willapa Bay, Washington with oysters from the East Coast and is carried to Oregon shores by ocean currents.

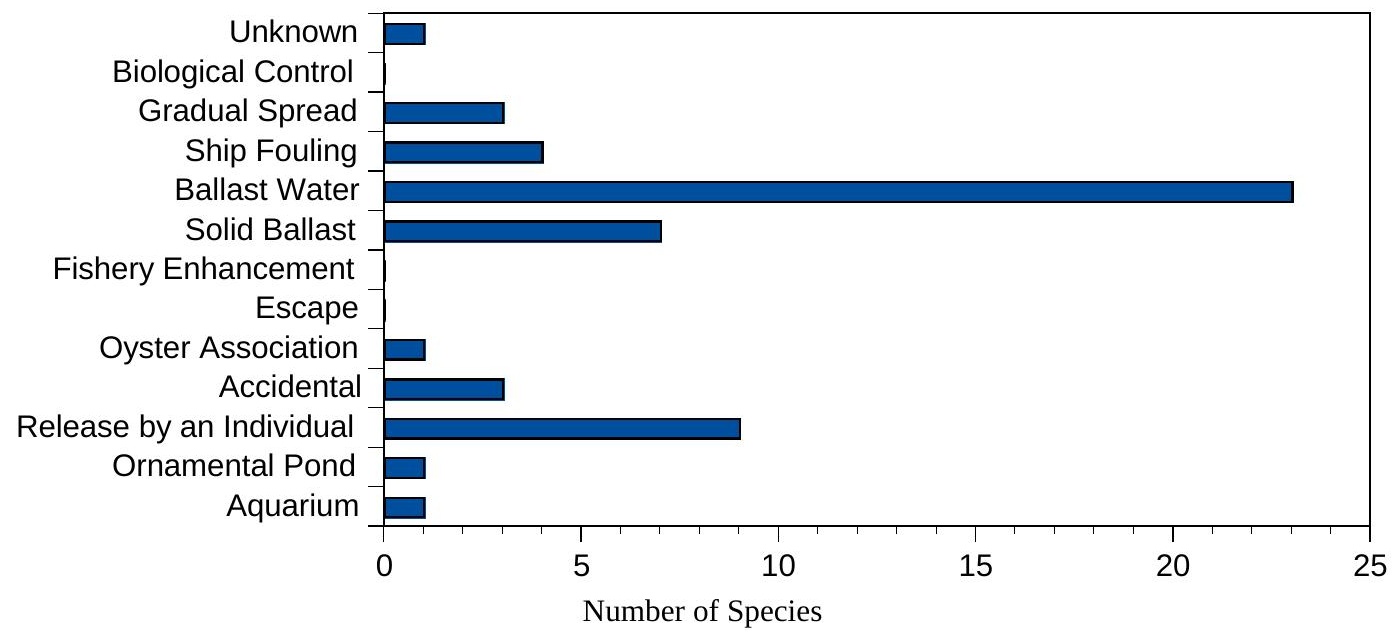

Figure 2. Pathways of introduction of invertebrates into the lower Columbia River (Sytsma, unpublished data).

Invasions by introduced species can occur rapidly and can quickly alter native plant and animal communities. The Asian clam (Potamocorbula amurensis), for example, was introduced into San Francisco Bay in ballast water. First detected in the bay in 1986, it only took only a few 
years for the benthic ecosystem of San Francisco to be converted into a monoculture of $P$. amurensis. The invasion resulted in displacement of native benthic organisms and alteration of the bay’s pelagic ecosystem by these filter-feeding clams, to the extent that the clam is suspected of being responsible for the collapse of some of the area fisheries (Carlton et al., 1990).

\section{Shipping-related Pathways of ANS Introduction}

With 80 percent the world's goods delivered by ships, it is easy to see why shipping has been identified as the predominant vector of ANS introductions in marine and estuarine ecosystems (USCG, 2003; Fofonoff et al., 2003). Shipping-related transport of ANS, which includes hull fouling, ballast (both solid and water), anchor chains, and sea chests, has been an important vector since the 1800s, when large sailing vessels began regularly plying the seas (National Research Council, 1996). More than 3,000 species of plants and animals are transported daily in ballast water (National Research Council, 1996). It is estimated that 21 billion gallons of ballast water containing thousands of ANS are discharged into U.S. waters each year (Moore et al., 1998). Large vessels are able to transport over five million gallons of ballast water per voyage. In a pioneering study done in Coos Bay, one vessel from Japan had 317 species in its ballast water (Carlton and Geller, 1993).

Ballast operations are an integral part of a vessel's operations, especially for cargo vessels. Ballasting helps maintain stability of the vessel under various loading conditions. Ballast is any solid or liquid placed in a ship to increase the draft, to change the trim, to regulate the stability, or to maintain stress loads within acceptable limits (National Research Council, 1996). Improper ballasting results in loss of trim (balance) and stability that could cause capsizing and makes steerage difficult if not impossible, and can result in hull stress that can lead 
to cracking (USCG, 2004). Vessels typically take on ballast water at their last port of call and discharge it, along with the biota it contains when they arrive at a new port. For a review of ballasting please see Report on the Oregon Ballast Water Management Program in 2002 (Vinograd and Sytsma, 2002).

Ballast water exchange (BWE), the process of exchanging port water with ocean water, is presently the most broadly applicable method for reducing the risk of ANS introductions (USCG, 2003; International Association for Great Lakes Research, 2002). It is typically conducted using a flow-through or empty-refill technique. Flow-through involves flushing a ballast water tank containing coastal or port water with ocean water from the bottom up. Although efficiency varies, pumping three times the tank volume through the tank is the operational standard. Emptyrefill, as the name implies, involves evacuating the ballast water taken onboard in port from the tank until suction is lost and refilling the tank with ocean water. The efficacy of ballast water exchange in reducing the risk of ANS introduction, however, is limited by a number of physical and biological factors associated with tolerance of organisms, constraints inherent in ship construction and operation, and ecological concerns including:

- some ships are not structurally designed to safely allow ballast water exchange at sea;

- exchange is sometimes impossible in rough weather due to safety concerns;

- some organisms can survive under a very wide range of salinity conditions;

- some ports have salinities very similar to mid-ocean salinities, which limits effectiveness;

- despite flushing of the ballast tanks with open ocean water, "pockets" of unexchanged water (and associated organisms) may remain in the ballast tanks;

- ballast water tanks often contain a layer of sediment, in which organisms can escape being flushed out in a ballast water exchange, to re-inoculate the exchanged ballast water;

- use of exchange in coastal voyages may result in spread of organisms along the coast and increase risk of introduction to estuaries that lack port facilities; and

- verification of exchange can be difficult, which complicates enforcement of exchange requirements (Vinograd and Sytsma, 2002). 
Because of these limitations, alternatives to ballast water exchange are being investigated. Alternatives include mechanical (filtration, cavitation), physical (UV light, heat, oxygen deprivation), and chemical (oxidizers, toxics) ballast water treatment, or combinations of these treatments (see Research section).

\section{Oregon Shipping and its Economic Impact}

Shipping, especially exporting, is critical to the Oregon economy. Exports from Oregon to Asian-Pacific markets alone amounted to \$5.1 billion in 2001 (Oregon Blue Book, Date accessed August 26, 2004). Major exports include wheat and cereal, vehicles, soda ash and pot ash, (Oregon Economic and Community Development Department, Date accessed August 26, 2004; Port of Portland [POP], Date accessed 8/26/04). The Portland metro region is the leader in export sales for the state, and ranks 11th of 253 in sales for U.S. metropolitan regions (U.S. Department of Commerce, 2001). In 2000, the shipping industry produced a total earnings and consumption impact in Oregon of about \$1.7 billion (POP, 2004).

The Port of Portland is an important part the shipping industry and has a significant economic impact in the state. It is the largest Columbia River port; it received 90 percent of the vessel calls in Oregon from January 2003 through July 2004. It is also the third largest export port on the west coast in total tonnage, exported container cargo is three times the imported container cargo (Wyatt, 2004); the largest wheat export port in the United States, exporting 40 percent of U.S. wheat (3 million short tons in 2003); and imports the largest volume of autos on the west coast (366,383 units in 2003) (POP, Date accessed August 24, 2004). Firms providing goods and services to support POP business activities received $\$ 4.5$ billion in business. Portlandarea residents received \$640 million dollars of POP-related direct earnings in 2000 (POP, 2004). 
The shipping on the Columbia changes in response to the changing global economy. The majority of the vessels stopping at Oregon and Columbia River ports are bulkers and container ships (Figure 3). Although recovery of container shipping is likely (S. Degens, POP, 9/23/04), the recent decline in the number of container lines calling on Columbia River ports suggest that bulkers and possibly barges will account for a larger proportion of ship calls in the immediate future. Because vessel types differ in their ballast management procedures, change in the proportion of vessel types visiting the Columbia River alters the volume and "quality" of ballast water discharged. Nevertheless, export of bulk cargo will undoubtedly dominate shipping on the Columbia in the future. Bulkers typically enter the Columbia empty, with ballast onboard, and can carry up to 5 million gallons of ballast water per ship (Carlton et al., 1995). A sustainable Oregon economy requires consideration and management of potential consequences and impacts associated with changing economic activity. Management of ANS introduced with ballast water is one such consequence.

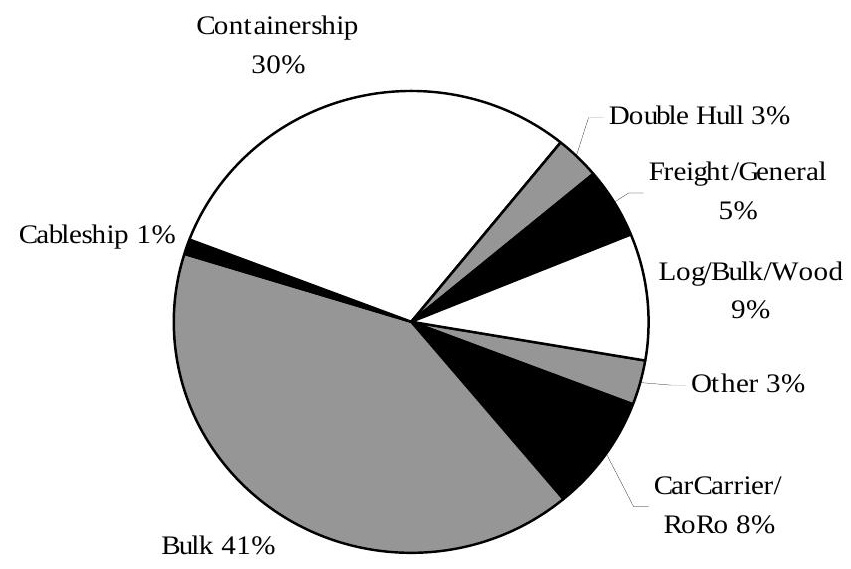

Figure 3. Vessel types stopping at Oregon and Columbia River Ports (01/01/03 to 06/30/04). (Data source: WDFW ballast water database.) 
Oregon has appropriated no resources for tracking ballast water management by ships calling on Oregon ports. The only data available for evaluating the impact of ballast water on Oregon are from the Washington ballast water database and the National Ballast Information Clearinghouse (NBIC). NBIC data are not available for 2004. Following, is a summary of shipping and ballast water management in Oregon, based primarily on the Washington Department of Fish and Wildlife (WDFW) ballast water data, with a comparison between NBIC and WDFW 2003 data.

According to ballast water reports submitted to and received by the WDFW, 2221 ships called on Columbia River (Oregon and Washington) and other Oregon ports; 1297 ships visited Oregon ports in the past year (July 2003-July 2004). The proportion of transoceanic and coastal shipping on the Columbia in 2003-2004 was similar to that in 2002 when 55 percent of the vessels came from outside the EEZ (Vinograd and Sytsma, 2002). For 2003-2004, 59 percent of the vessels traveled coastally, while 41 percent of the ships were transoceanic vessels, (arriving from outside the U.S. exclusive economic zone [EEZ] (Figure 4)). The majority of transoceanic vessels (94 percent) were from Asian ports (Figure 5). Most of the “Asian” vessels originated from Japan (56 percent) followed by South Korea, China and Taiwan. Vessels traveling coastally primarily enter Oregon waters from British Columbia (43 percent); Washington (28 percent) and California (25 percent) (Figure 6).

The data suggest that barges are not consistently reporting ballast operations. WDFW data indicated that 565 barges submitted ballast water reports and called on the Port of Portland during the 2003-2004 period (one called on the Port of Longview). These numbers differ from Port of Portland information, and barges appear to be under-reported. Ocean-going and river barges operate on the Columbia. Most operate predominantly on the Columbia/Snake/Willamette 
Rivers, however, there is regular barge traffic between Puget Sound and the Columbia River.

There is biweekly barge service from Longview to Hawaii and aggregate and timber transport to and from multiple locations on the west coast (S. Degens, POP, pers. com. 09/23/04). The operations and risk of ANS introduction posed by barging on the Columbia River requires additional research and discussion.

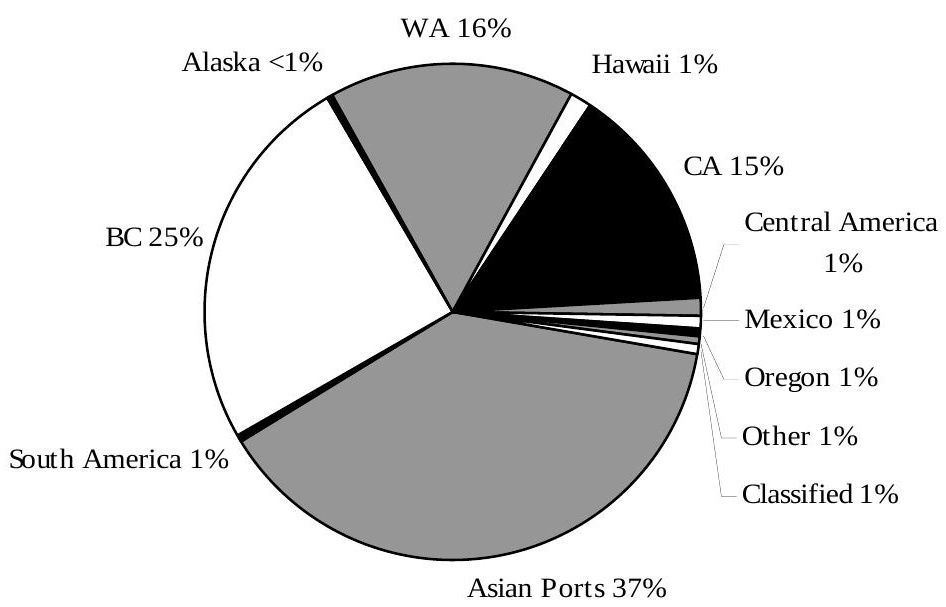

Figure 4. Last port of call for vessels entering Oregon ports (07/01/03 to 06/31/04). (Classified vessels are military vessels. Data source: WDFW ballast water database.)

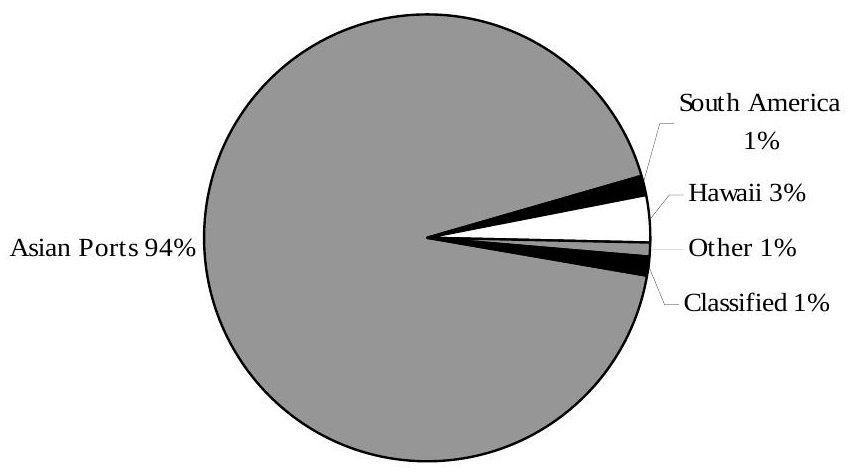

Figure 5. Distribution of last port of call for transoceanic voyages to Oregon ports (07/03 to 07/04). (Classified are vessels are military vessels. Data source: WDFW ballast water database.) 


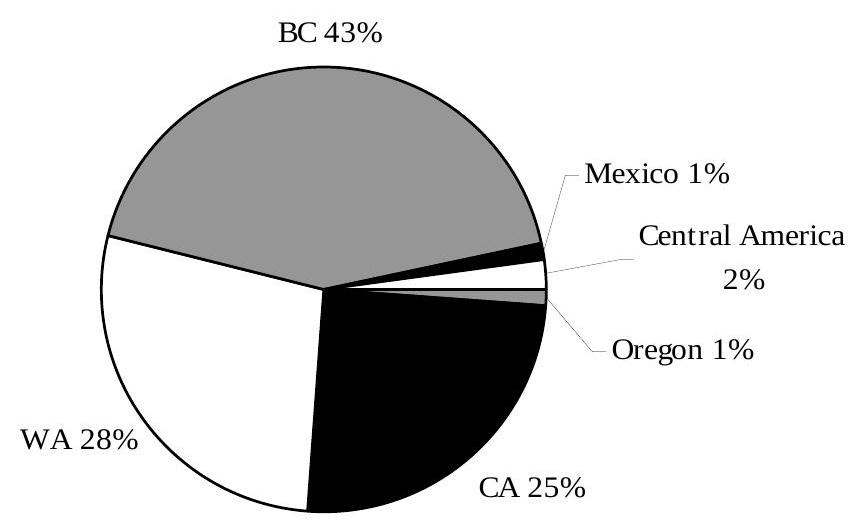

Figure 6. Distribution of last port of call for vessels traveling coastally (07/01/03 to 06/30/04). (Data source: WDFW ballast water database.)

\section{Oregon Ballast Water Regulation Compliance}

As noted above, no funds were available for monitoring ballast water reporting and management in Oregon in 2004, but the WDFW monitored ballast water reporting for Columbia River ports (including Oregon ports) and other Oregon ports. Federal law also required reporting of ballast water management (for ships from outside the EEZ) to the National Ballast Information Clearinghouse (NBIC). The WDFW data provides the only information on compliance and ballast water discharge into Oregon waters from coastal shipping.

The WDFW enters information on ballast water management reported by vessels on a ballast water reporting form, which is provided by the Merchants Exchange in Portland. The Merchants Exchange also distributes the forms to the NBIC, the Oregon Department of Environmental Quality (DEQ), and to Portland State University (PSU). The WDFW monitors the Lightship Report of vessel arrivals and matches it with ballast water reports. When a vessel arrives and no ballast water management report is available, WDFW contacts the Merchants Exchange and/or the agent. WDFW evaluates locations of reported ballast water exchange for compliance with Washington law, but not for Oregon law (P. Meacham, pers. com., 08/25/04). 
Since requirements for coastal exchange differ between states, and because the Columbia River receives a high percentage of coastal traffic, our ability to evaluate compliance of ballast water management activities with Oregon law is limited.

Compliance with reporting requirements of Oregon law was much lower than in 2002, when compliance was 98.5 percent (Vinograd and Sytsma, 2002). According to WDFW data, 60 percent of ships calling on Oregon ports in 2003-2004 were in noncompliance, when they either failed to report (29 percent); submitted incomplete reports (30 percent), or submitted late reports (one percent) (Figure 7). As was noted by Vinograd and Sytsma (2002), compliance is highly correlated with staffing level. In 2002, a PSU graduate student was available to follow up on missing and incomplete reports.

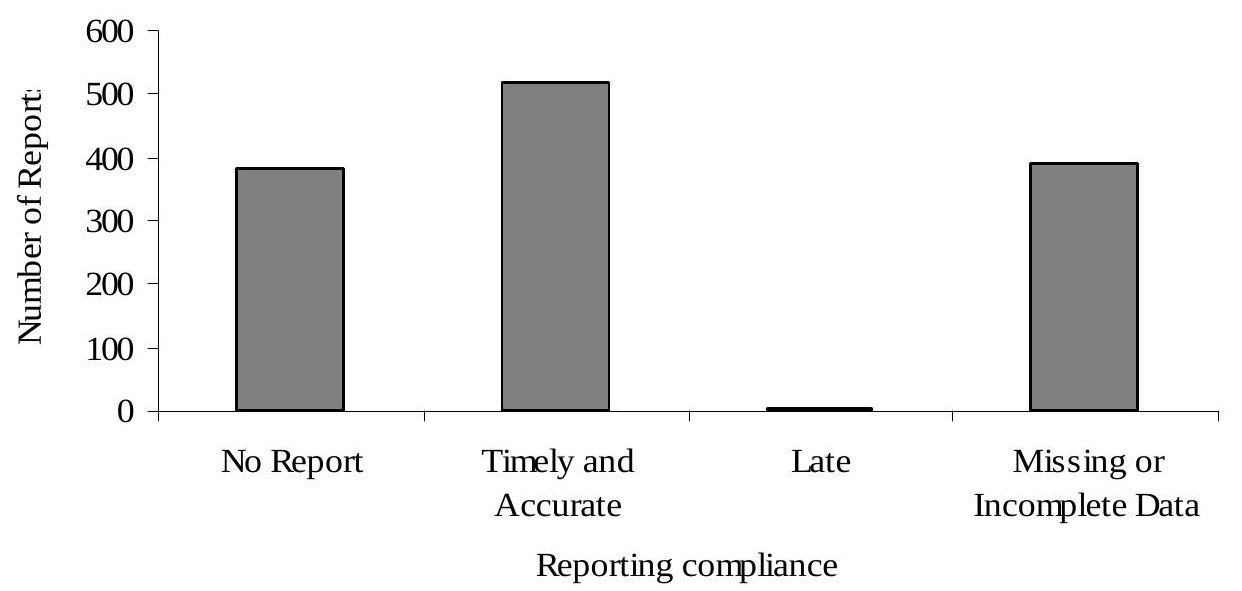

Figure 7. Reporting compliance for vessels entering Oregon ports between 07/01/03 to 06/30/04. (Data source: WDFW ballast water database.)

The National Invasive Species Act (1996) (NISA) directed the U.S. Coast Guard to work with the Smithsonian Environmental Research Center (SERC) to develop a national ballast water database -NBIC. The NBIC is located at the SERC, and is part of a larger program that addresses aquatic bioinvasion patterns and processes. The development of the database was a key 
element in NISA - it was required to track the effectiveness of the voluntary (now mandatory) ballast water management guidelines. The primary goals of the NBIC are to track the volume, origin, and treatment of ballast water that is discharged into U.S. waters (NBIC, Date accessed 08/28/04).

The WDFW ballast water database contains 35 percent more ballast water reports than the NBIC database for 2003 for transoceanic vessels (Table 1). All vessel types excluding the “Other” category are higher for WDFW data than NBIC. In some cases, entire vessel types were missing from NBIC, such as Log/bulk vessels, 37 reported to WDFW, while the NBIC database shows no Log/bulk vessels. Similarly, 25 woodchip vessels submitted reports to WDFW but none were submitted to NBIC (Table 1). The reason for the discrepancy is unknown, however, a new, ballast water reporting project between the NBIC and PSU should assist in clarifying the situation.

New rules and reporting capabilities should enhance reporting. Recently, the USCG established mandatory penalties for non-submittal of ballast water reports and encouraged the use of electronic reporting with newly developed forms for easier use. Electronic reporting has automated "receipts", and formatting restrictions will minimize to mis-entry. The forms can be accessed, and filled out online, and be transmitted automatically (USCG, 2004). 
Table 1. Number of ballast water reports to WDFW and NBIC for vessels from outside the EEZ from 01/01/03 to 12/31/03. (Data source: WDFW ballast water database and NBIC 2003 data.)

WDFW NBIC

\begin{tabular}{ccc}
\hline Bulk & 268 & 211 \\
RoRo/PCC & 152 & 106 \\
Container & 45 & 18 \\
Log Bulk & 28 & 0 \\
Tanker & 25 & 18 \\
Wood Chip & 25 & 0 \\
Unknown & 12 & 8 \\
General Cargo & 20 & 14 \\
Cable Ship & 3 & 0 \\
Passenger & 1 & 1 \\
Other & 15 & 18 \\
Classified & 10 & 0 \\
All Types & $\mathbf{6 0 4}$ & $\mathbf{3 9 4}$
\end{tabular}

Unexchanged ballast water is considered the highest risk ballast water and under Oregon law its discharge is prohibited with a few exceptions. Based on the 40 percent of the ships that reported to WDFW, 3,190,366 cubic meters was discharged into Oregon waters, 9\% of that was unexchanged ballast water between November 2003 and March 2004. The greatest number of vessels discharging unexchanged ballast water were vessels from Asian ports -56 percent, (e.g., China, South Korea, Japan), 19 percent was from the San Francisco Bay area, and 19 percent was from regional or coastal waters (excluding California) (Figure 8). Oregon law does not prohibit discharges of unexchanged ballast water from vessels traveling within defined common waters (between the parallel 40 degrees north latitude and the parallel 50 degrees north latitude, ORS 783.630), if that ballast water is not mixed with any other water. Therefore, some of the unexchanged ballast water from regional and coastal ships may have been discharged legally. Bulk vessels, the most common vessel-type calling on Columbia River ports account for most of the unexchanged (56 percent) and partially exchanged (67 percent) ballast water. 


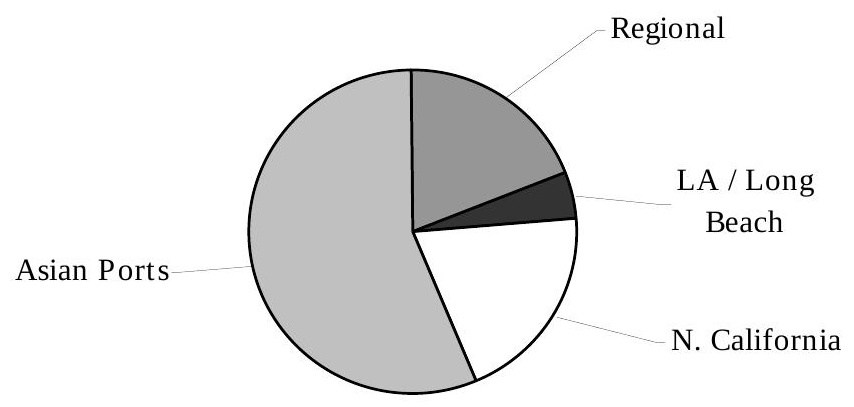

Figure 8. Breakdown of origin of discharged unexchanged ballast water in Oregon waters 11/03 to 03/31/04. (Data source: WDFW ballast water database.)

The flow-through method is the most common ballast water management strategy employed by vessels entering Oregon waters (Figure 9). In flow-through exchange, the amount of ballast water exchanged varies with the amount of ballast water that is pumped through each tank. USCG, California, Washington, the International Maritime Organization (IMO), and Canada all define "exchange" and the standard for each process, and can therefore evaluate the completeness of the ballast water exchange reported. Oregon law does not define exchange, and the efficacy of the exchange reported cannot be evaluated. 


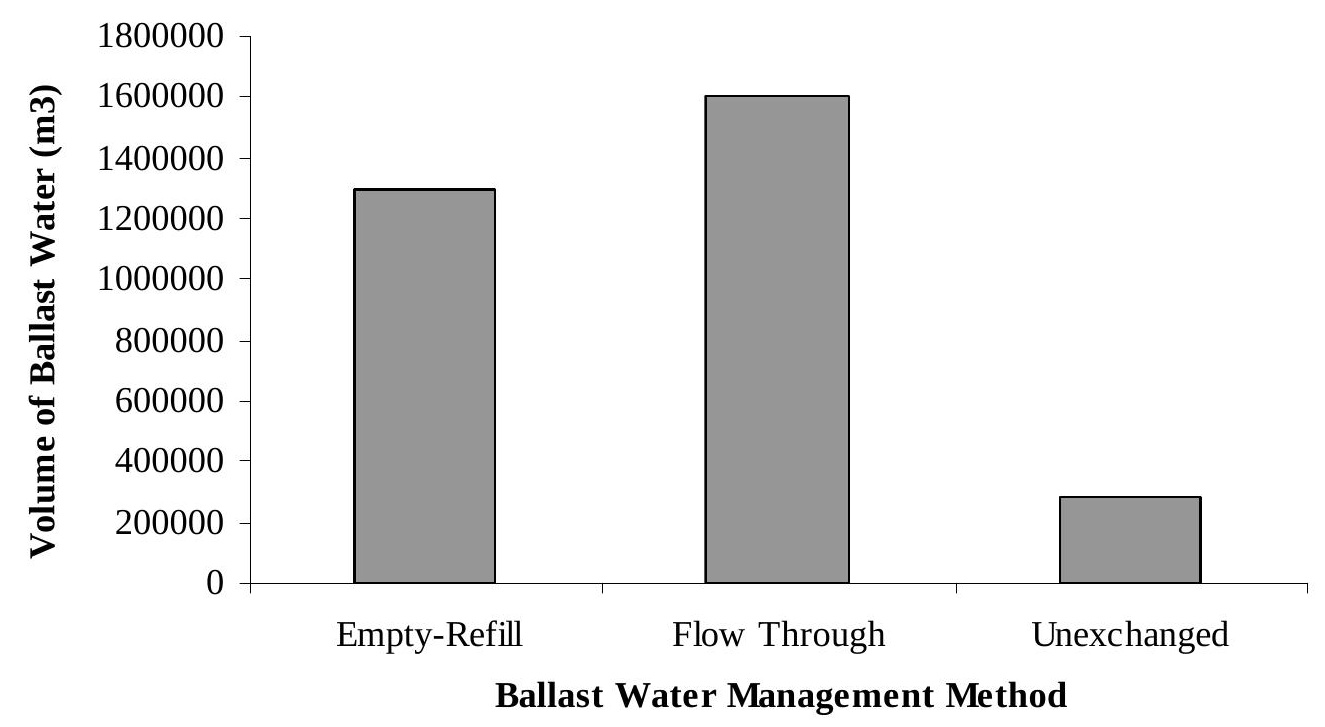

Figure 9. Volume of ballast water discharged into Oregon waters following flow-through, empty-refill, and no exchange, 11/01/03 to 03/31/04. (Data source: WDFW ballast water database.)

The risk of introduction of ANS via ballast water discharge is directly related to the source of that ballast water. California ports, especially those in the highly invaded San Francisco Bay - Delta area, are a high-risk source for Oregon ports. Of those ships arriving to Oregon with a California port as a last port of call, about 60 percent come from a port in the Bay - Delta area (Figure 10). Ports upriver from the Carquinez Straight are freshwater, or seasonally freshwater, and could contain ANS that could easily become established in the Columbia River. Organisms from ports with high salinity may become established in mesohaline and polyhaline portions of the Columbia River estuary or in other Oregon estuaries receiving ballast water from the bay area. 


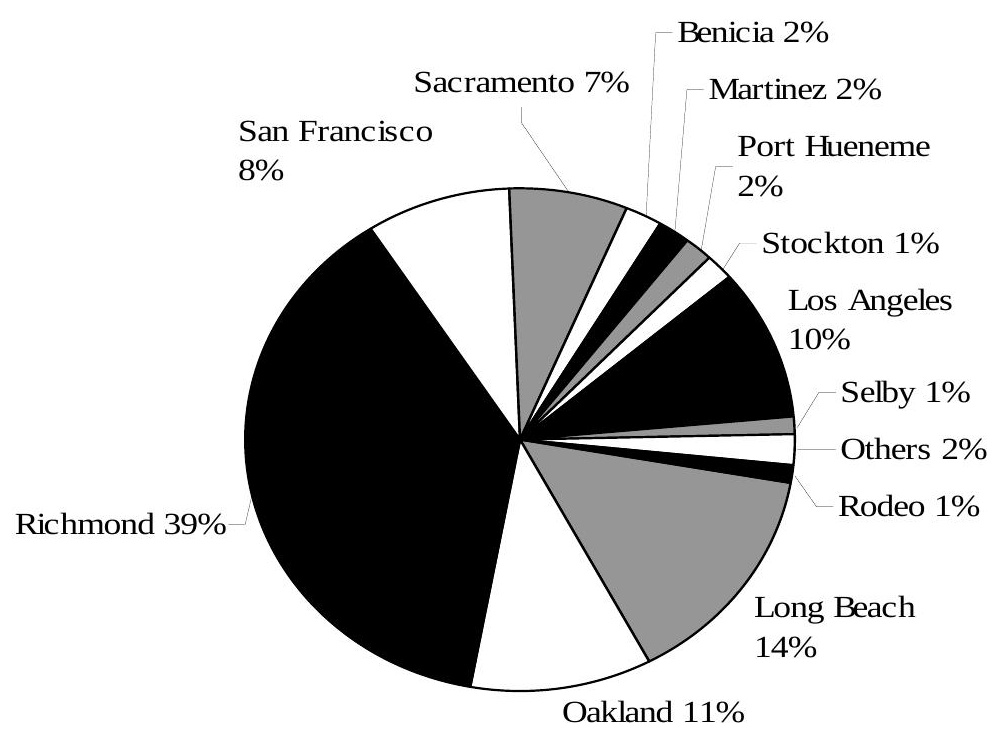

Figure 10. California ports reported as last port of call for ships calling on Columbia River ports (Other = Avon, Alameda, Ensenada and Eureka. Data source: WDFW ballast water database).

\section{Data Quality}

Accurate data is critical for enforcement and monitoring of compliance with ballast water management regulations. Data based upon ballast water reports alone should be used with caution. According to a study done between June and August of 2002 to assess the accuracy of ballast water reporting in Washington, ballast water reports often contain errors. Of 81 vessels inspected, 27 had conflicting data, 24 had improperly exchanged ballast water, and 20 vessel operators knowingly discharged improperly exchanged ballast water (Harkless, 2003). Several reasons for conflicting data were cited. The most common reason cited by operators for the inaccuracies in the reports was the lack of ability of regulators to identify the violation. Other reasons for inaccurate reporting included lack of knowledge of the ballast water regulations, the cost of ballast water exchange, and additional work it required. Adequate staff for follow-up on problem or missing reports would improve the data, help fine tune the cost-effectiveness of the regulations, and potentially improve compliance. 


\section{Other Ship Mediated Vectors of ANS: Hull Fouling, Sea Chests and Anchor Chains}

Many marine and some important freshwater (e.g., zebra mussel) invasions in North America have occurred in the fouling community - the organisms that grow attached to surfaces. These organisms may have arrived on the hulls of ships, in sea chests (a boxlike inlet for raw water cooling of the ship's engine), or on anchor chains. The cumulative surface area of ships' hulls arriving annually to U.S. ports from a different biogeographic region exceeds 400 million $\mathrm{m}^{2}$, or approximately 1.5 times the area of Vermont (Ruiz et al. 2003). Several recent analyses have also underscored the importance of ANS transfers on the hulls of commercial ships. For example, non-native species were discovered on 96 percent of all commercial ships’ hulls examined in Germany (Gollasch, 2002). Hewitt et al. (2004) suggested hull fouling was the likely vector for most ship-mediated invasions in Port Philip Bay, Australia. Unfortunately, hull fouling as a vector may increase with regulated changes in anti-fouling bottom paints (Nehring, 2001; Minchin \& Gollasch, 2003).

Despite the clear potential for transport on ships’ hulls, quantitative assessment of the importance of hull fouling in the transport of ANS, the extent to which this varies by ship type, operating conditions, residence times in port, routes, hull husbandry; and the relative contribution of transfers in ships ballast water versus on ships hull (biofouling) is not known. Management of hull-fouling ANS is currently limited to periodic hull cleaning in drydock, while management of biofouling on propellers is part of regular maintenance during port stops according to conversations with the maritime industry (M. Falkner, pers. com., 09/17/04). Hull fouling is an active area of research at Portland State University and ongoing efforts are discussed in more detail below. 


\section{Legislation and Management}

There has been considerable attention in the national and international arena on ballast water legislature and research since submission of the 2002 Oregon Task Force ballast water report to the legislature. The USCG published new rules; the IMO adopted a Convention on ballast water and sediment management in February; the California State Lands Commission (CSLC) is developing regulations governing ballast water management on vessels engaged in coastal travel; Washington Department of Fish and Wildlife began a monitoring and compliance program, and the Canadian Marine Advisory Council (CMAC) published draft regulations that will take the place of the current guidelines. Table 2 summarizes the status of regulations, which are discussed in more detail below. 
Table 2. Comparison of international, Canadian, federal, and state ballast water regulations.

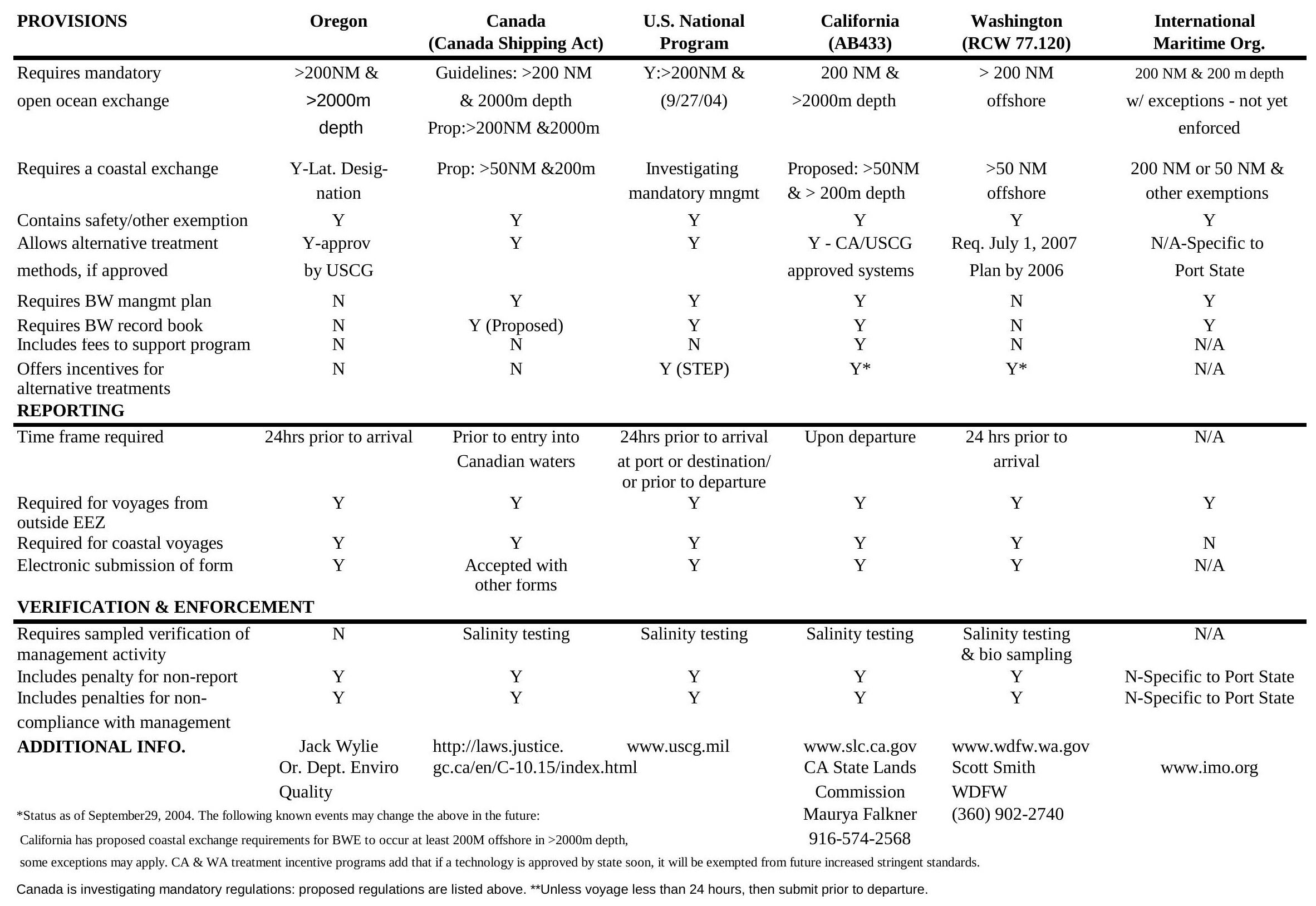




\section{Oregon}

The Oregon ballast water management program was initiated in January 2002 following passage of SB 895 by the Oregon legislature during the 2001 session. The Oregon Department of Environmental Quality (DEQ) has authority for implementing the program. The program requires exchange of ballast water in coastal and transoceanic shipping and reporting of ballast water management activities to DEQ. The program was modified by the legislature in the 2003 session in HB 3620. Major modifications included removal of sediment from the definition of ballast water, provision for alternative methods of conducting coastal exchange, and allowance for discharge of treated ballast water. Specifically, the Oregon ballast water management program currently includes:

- A task force on ballast water management to research and make recommendations to the legislature.

- A requirement that vessels submit ballast water management reports on a form acceptable to the USCG, to the Department of Environmental Quality at least 24 hours prior to entering the waters of this state, whether or not the owner or operator plans to discharge ballast water into the waters of this state.

- A requirement that the vessel conduct an open sea or coastal exchange unless;

o The vessel traverses only the internal waters of the state or only the territorial sea of the United States and does not enter or depart an Oregon port, or navigate the waters of the state, or;

o The ballast water on coastal vessels has been replaced in accordance with regional or federal guidelines that are equally or more protective than the methods provided above (added in SB 895);

- Prohibition of the discharge of ballast water into the waters of the state unless:

o The vessel discharges ballast water that has been treated to remove organisms in a manner that is approved by the United States Coast Guard. 
The Oregon ballast water management program does not include regulation of the uptake of sediment and its accumulation in ballast water tanks or a requirement for a ballast water management plan and record book, as is required in California and under federal law.

Oregon defines “open sea exchange” as replacement of ballast water taken on in port with mid-ocean water from an area no less than 200 nautical miles (NM) from any shore and where the water depth exceeds 2,000 m. “Coastal exchange” applies to vessels that do not travel more than 200 NM from shore. For vessels traveling south to Oregon an exchange north of $50^{\circ} \mathrm{N}$ latitude is required. For vessels traveling north to Oregon an exchange south of $40^{\circ} \mathrm{N}$ latitude is required (Figure 11).

These regulations apply to “cargo vessels” which are considered self-propelled ships in commerce, other than a tank vessel or a vessel used solely for commercial fishing harvest of 300 gross tone or more (ORS 783.625). Integrated tug-and-barge (ITB) and articulated tug-andbarge (ATB) may be considered “self-propelled” vessels. The U.S. Coast Guard requires ballast water reports from these vessels. There are discrepancies in the numbers of barges submitting reports and the number calling on Oregon ports, and it is not clear whether these vessels are reporting to Oregon. Outreach and consultation with the barge operators is required to clarify reporting requirements. 


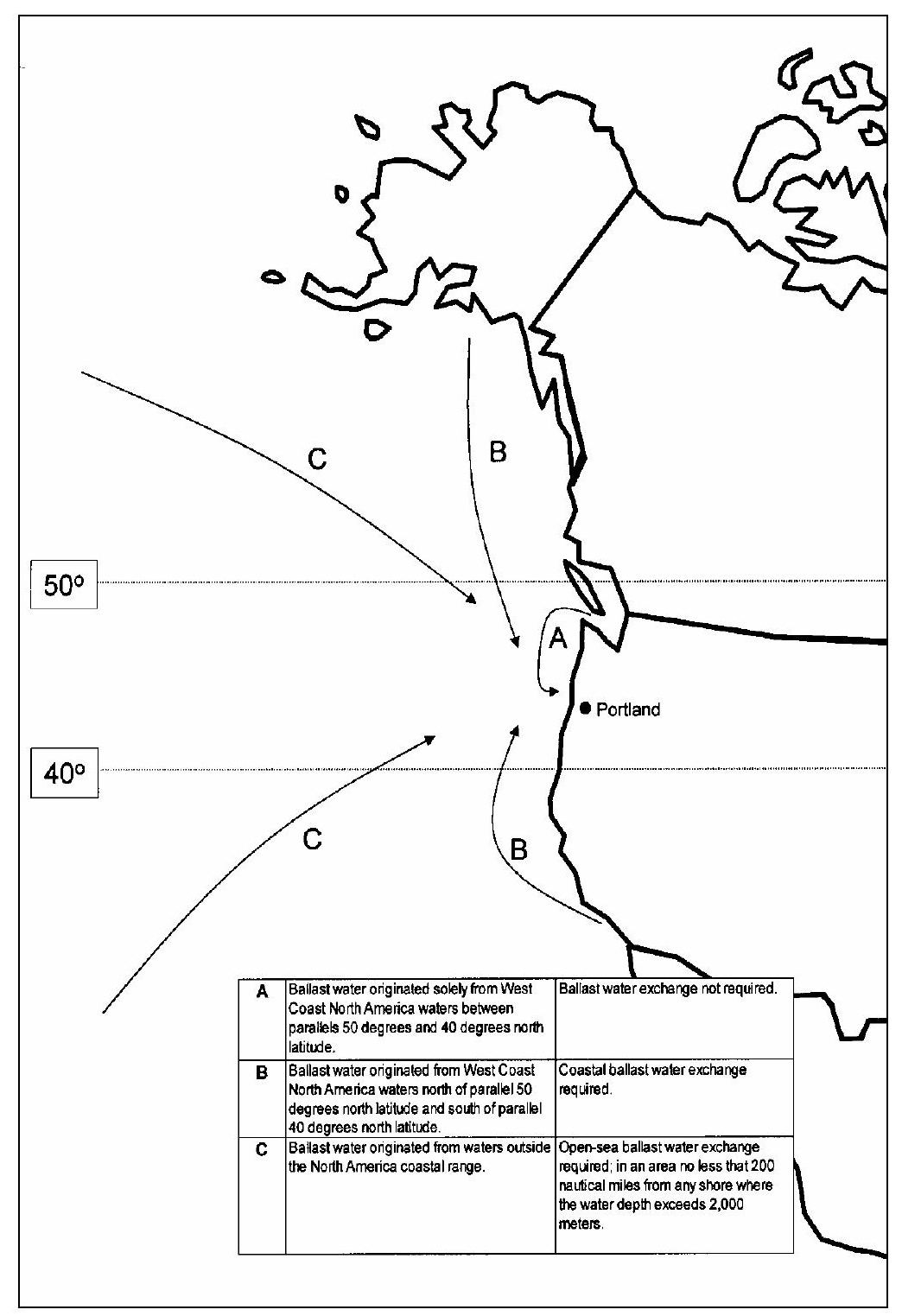

Figure 11. Schematic of the Oregon coastal ballast water exchange requirement (Source: Vinograd and Sytsma, 2002)

As noted above, DEQ has not allocated funds for implementation of the ballast water management program and no funds were directed to the program by the legislature.

Consequently, information on ballast water management in Oregon is limited. During the first year of the program the Center for Lakes and Reservoirs at Portland State University (PSU) secured support from PSU, the Columbia Steamship Operators Association (CRSOA), and the Pacific States Marine Fisheries Commission for tracking ballast water management reports and 
maintaining a database. Since 2003, ballast water management reports have been logged into a database maintained by the WDFW.

DEQ is authorized to take enforcement action for violations. DEQ may levy a civil penalty for violations, (not to exceed \$5,000 per discharge violation, and \$500 for a violation of the reporting requirements); however, no fines have been imposed. Since the program was implemented in January 2002, DEQ has issued two Notices of Noncompliance. In both instances, the vessel operators replied that they had notified all their vessel masters of the requirements of Oregon law.

Oregon law permits discharge of ballast water treated with a method approved by the USCG. To date, no treatment technologies have been approved, however, there are two applications in review in the USCG Shipboard Technology Evaluation Program (STEP) discussed in more detail in the Research section of the report (K. Moore, pers. com., 08/26/04). California and Washington also have processes for approval of experimental treatment technologies for testing and evaluation purposes. The California program is coordinated with the USCG STEP. The Washington program has approved installation and testing of treatment technologies on two cruise ships (described below).

Oregon law prohibits discharge of ballast water treated with Washington-approved methods if the method is not approved by the U.S. Coast Guard. Therefore, a ship with Washington-approved technology onboard that discharged into the Columbia River would be in violation of Oregon law but in compliance with Washington law. Washington law requires consideration of Oregon law in development of regulations on the Columbia River. Oregon law has no reciprocal requirement, but WDFW is a member of the Oregon Ballast Water Task Force 
and provides input to the Oregon program. The Task Force and past legislatures have emphasized the need for a consistent, federal ballast water program that is protective of Oregon waters and expressed a clear preference for a single, U.S. Coast Guard-led, treatment approval process.

Oregon and Washington have differing regulations for management of ballast water in coastal shipping. Oregon law establishes boundaries based on latitude, as described above, whereas Washington law requires exchange greater than 50 NM from shore. Oregon law was amended during the last legislative session to allow discharge of coastal ballast water exchanged following regionally of federally approved protocols. Protocols were developed at a conference in California in April 2004 (see below) that are based upon recently approved IMO regulations. The protocol uses 50 NM and 200 m depth criteria for exchange of coastal ballast water. Oregon law should be amended to comply with the $50 \mathrm{NM} / 200 \mathrm{~m}$ criteria. If applied by all west coast states, this protocol would be more protective of Oregon waters than current regulations based upon latitude.

\section{Washington}

The Washington Department of Fish and Wildlife (WDFW) manages the Washington ballast water program. The program is covered under Washington law (Title 77 Fish and Wildlife, Chapter 77.120 RCW Ballast Water Management under SSB 6329). The regulations require that vessels subject to this law (vessels of 300 gross tons or greater, excluding military vessels), which intend to discharge in the waters of the state, must report ballast water management information at least twenty-four hours prior to their arrival (Ch. 77.120 RCW; Ch. 220.77 WAC). Both USCG forms and IMO forms are acceptable, although USCG forms are 
preferred. Reports are sent to the Merchants Exchange appropriate to the vessel's destination.

Washington law also stipulates that WDFW consider the special case of the shared waters of the

Columbia River system, and must consider the rules adopted by the state of Oregon when

adopting rules under this section for this water system.

For all vessels entering Washington waters from outside the exclusive economic zone

(EEZ) or traveling coastally, a vessel can discharge ballast water in the waters of the state provided that:

- the vessel has conducted an open sea exchange, except in cases where it is not safe to conduct one, or;

- beginning on July 1, 2007, discharge is authorized only if there has been an open sea exchange or if the vessel has treated its ballast water to meet standards set by the WDFW, at which point the safety exemption will no longer be allowed.

- Vessel operators are required to submit a report to WDFW by July 2006 describing how they will meet the July 2007 requirement to treat their ballast water when an exchange is not possible.

Other exchange exemptions are as follows:

- When a ship's ballast water is common to the state and has not been mixed with waters or sediments from outside the Columbia River (north to the Strait of Juan de Fuca, inland waters of Puget Sound, the Strait of Juan de Fuca, and the Strait of Georgia south of $50^{\circ} \mathrm{N}$ latitude).

- When a Washington state approved ballast water treatment system is used that meets Washington State ballast water discharge standards.

(Adapted from Ch. 77.120 RCW and Ch. 220.77 WAC.)

“Open sea exchange” is defined for vessels from outside the EEZ as exchange at least 200 NM offshore; for vessels traveling coastally, exchange must be conducted at least 50 NM or more offshore (RCW 77.120.030). Washington law also includes the provision that if the USCG requires a vessel to conduct an exchange further offshore, then the USCG distance governs. 
Under Washington regulations, “exchange” is defined as replacing water in a ballast tank either using flow-through, an empty/refill process, or other exchange methodology as recommended or required by the USCG. "Flow-through exchange" is defined as flushing out ballast water by pumping mid-ocean waters from the bottom of the tank, and continuously overflowing the tank from the top until three full volumes of water have been changed to minimize the number of original organisms remaining in the tank (RCW 77.120.005). "Empty/refill exchange” means to pump out the tank until it is empty or as close to the master or operator determines is safe such that the ballast water taken on in the ports, estuarine waters or territorial waters, and then refilling the tank with open-sea water (RCW 77.120.005).

Washington Department of Fish and Wildlife have established interim ballast water discharge standards to provide a treatment target for technology developers (WAC 220-77-095). The standard is inactivation or removal of 95 percent of zooplankton and 99 percent of phytoplankton and bacteria in ballast water. As noted above, Washington has an interim approval process to evaluate treatment technologies and provide approval for technologies that meet the standards. Only those technologies, vendors, and vessels that have approval will be allowed to discharge treated ballast water into Washington waters. The regulations also require that, where appropriate, these standards are to be compatible with standards set by the USCG and shall be developed in consultation with federal and state agencies to ensure consistency with the Federal Clean Water Act, 33 U.S.C. Sec. 1251-1387 (WAC 220-77-095). See research section below for more information.

Funding for the ballast water program in Washington has decreased (S. Smith, pers. com., 8/24/04), but WDFW has maintained the program with reduced staff and grant funding. They currently maintain a database for ballast water reports for Washington and Oregon and are 
monitoring compliance. Results from the Washington program indicate that compliance with reporting requirements is correlated with staffing levels. Reporting compliance decreases when staffing levels are reduced (Figure 12).

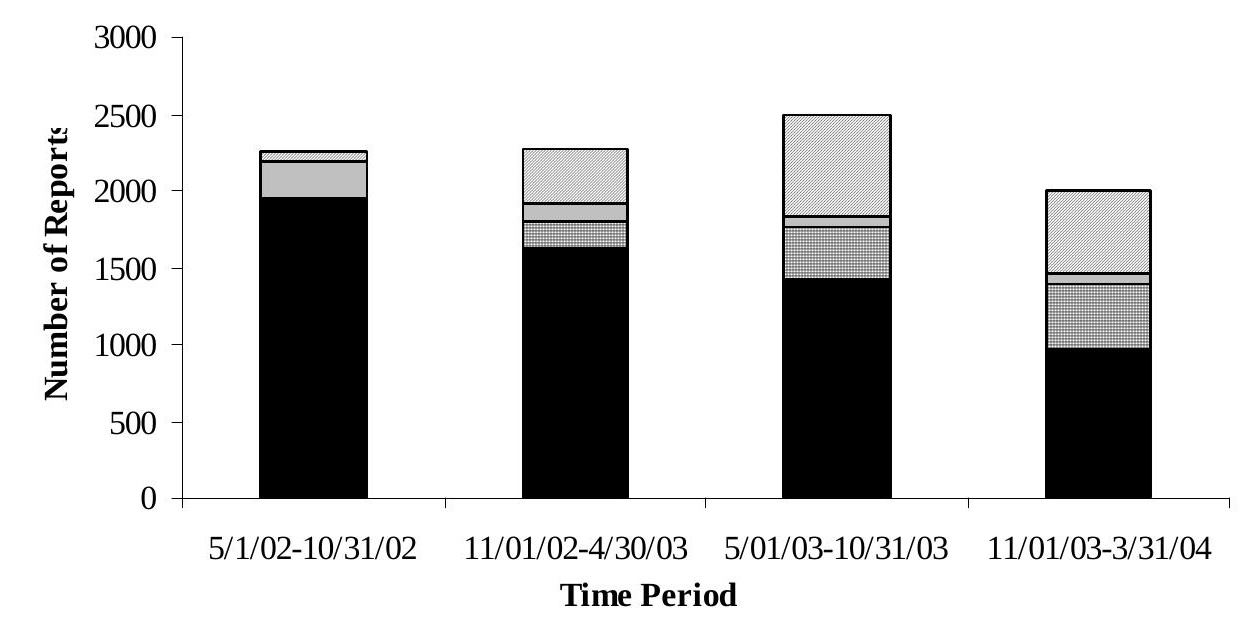

Complete \& Timely $\quad \square$ No Report $\quad \square$ Late Report $\quad \square$ Incomplete Data

Figure 12. Reporting compliance for Washington and Oregon Ports from May 2002 to March 2004 (data from WDFW ballast water reporting database)

WDFW recently hired a vessel inspector to review ballast water management practices and to collect ballast samples for analysis by the University of Washington and the U.S.

Geological Survey. The analysis will evaluate the presence of coastal and oceanic organisms as a method of verifying ballast water exchange (S. Smith, pers. com., 06/29/04). The inspector will also examine ballast water logs and complete a boarding report that produces a compliance score. Letters indicating level of compliance based on the compliance score will be sent to vessel owners and operators and kept on file at WDFW. The approach is intended to educate and inform vessel owners and operators of Washington regulations, reward low-risk vessel operators and owners, and provide high-risk owners and operators with an incentive to increase their compliance and hence decrease the potential for harmful biological invasions. In addition to the 
vessel inspector, one FTE is dedicated to managing the ballast water reporting database and compliance.

Compliance with reporting requirements has been a problem in Washington. Only ships which discharge in Washington waters are required to submit a ballast water management report. Washington has the authority to fine for non-compliance with reporting requirements, but since all ships are not required to report it is difficult to identify ships that are out of compliance with limited staff availability. Data from November 2003 - March 2004 indicated that only 34 percent of vessels reporting to WDFW were in full compliance with Washington reporting requirements during that time (S. Smith, pers. com., 06/29/04). A recent (August 13, 2004) USCG rule final rule that requires all vessels report ballast water management to the NBIC, and includes a substantial penalty for failure to report. This new rule should improve compliance with reporting regulations.

\section{California}

The California’s Ballast Water Management and Control Act of 1999 went into effect January 1, 2002 under the jurisdiction of the California State Lands Commission (CSLC). Three other California agencies; the Department of Fish and Game (DFG), State Water Resources Control Board (SWRCB), and the Board of Equalization (BOE), also had responsibilities under the law.

During 2000-2004, over 25,000 qualifying voyages were subject to the California law. Greater than 90 percent compliance has been attributed to good communication between the maritime industry, environmental organizations, and other regulating entities; extensive outreach by CSLC staff; the development of a Technical Advisory Group (TAG); implementation of a 
monthly electronic notification system; and the potential for civil penalties (Falkner, 2004). The two CSLC Marine Facilities Division Field Offices have boarded and inspected over 2700 different vessels and approximately 21 percent ( 5400) of the qualifying voyages during the first 48 months of the Program (Falkner, 2004). The majority ( $\geq 75$ percent) of those vessels boarded were found in compliance with the law. In addition to compliance monitoring, the California ballast water program supports research on ballast water treatment technology and the impacts of invasive species (see Research section below, pg. 60).

California’s “Marine Invasive Species Act” (AB 433) (Act) reauthorized and enhanced the statewide mandatory ballast water management and control program, effective January 1, 2004. The Act requires that the vessel master, owner, operator, agent, or person in charge of every vessel entering a California port or place regardless of origin, complete and submit a ballast water report form. All vessels are required to maintain a ballast water management plan specifically tailored to the vessel, maintain a ballast water log, adopt ballast water "Good Housekeeping” practices, and pay a fee for each qualifying voyage. A ballast water plan is a document specific to each vessel or class of vessel that in general contains:

- information regarding the ballast tanks on-board, place, size, through hull and on deck access points;

- up-to-date information on any of the machinery involved such as pumps;

- describes the duties and position of crew members who are involved in ballast water management;

- describe training protocols on ballast water duties;

- describe best management practices, such as minimizing sediment uptake, and

- if appropriate, give instruction on and ballast water treatment systems.

A ballast water record book is a recording of all ballast water management that takes place during a voyage such as when ballast water is taken on board, when it is circulated for management reasons, treated or discharged and is made available upon request (IMO, 2004a). 
The fee (currently $\$ 500$ at the first port call in California) is paid to the BOE, and is deposited into the Marine Invasive Species Control Fund, which is used to operate the program. Failure to comply with any portion of California law can result in civil and criminal penalties.

The California law applies to qualifying vessels, which are vessels over 300 gross registered tons capable of carrying ballast water into the waters of the state after operating outside the waters of the state. The California law applies to qualifying vessels, which are vessels over 300 gross registered tons capable of carrying ballast water into the waters of the state after operating outside the waters of the state. Under California law the U.S. Registered Tonnage Certificate number (GRT) is to be used for tonnage determination, however for most foreign vessels entering California from outside the EEZ, the International Tonnage Certificate (ITC) is normally used, unless the vessel does not have an ITC (M. Falkner, pers. com., 09/17/04). Qualifying vessels are required to conduct at least one of the following methods of ballast water management:

- mid-ocean exchange of ballast water outside the EEZ, from an area not less than 200 NM from any shore and in waters more than 2000 m deep;

- retain all ballast water on board;

- discharge ballast water at the same location where it originated providing that the master, operator, or person in charge of the vessel can demonstrate that the ballast water to be discharged was not mixed with any taken on in an area other than midocean waters;

- $\quad$ use an alternative, environmentally sound method of ballast water management approved by the CSLC or the U.S. Coast Guard before the voyage begins;

- $\quad$ perform a ballast water exchange within an area agreed to by the CSLC in consultation with the U.S. Coast Guard at or before the time of the request, or;

- discharge the ballast water to a reception facility approved by the CSLC (AB 433).

Under California ballast water management “exchange” is defined as replacing water in a ballast tanks using one of the following methods: 
1) "Flow-through exchange" refers to flushing out ballast water by pumping three full volumes of mid-ocean/near-coastal waters through the tank continuously displacing water from the tank, to minimize the number of coastal organisms in the tank (AB 433).

2) "Empty/refill” exchange means to pump out, until the tank is empty or as close to 100 percent empty as is safe to do so, the ballast water taken on in ports, estuarine or territorial water, and then to refill the tank with mid-ocean waters (AB 433).

California defines “mid-ocean” as waters that are more than 200 NM from land and at least 2,000 m deep.

The CSLC implements an extensive monitoring program to ensure compliance. All vessels are required to submit to compliance inspections, which include sample collection of ballast water and sediment, examination of documents, and any additional appropriate inquiries as needed. The Act specifies that field inspection of ballast water and sediments be conducted from at least 25 percent of the arriving vessels, with enforcement administered through the imposition of administrative civil and criminal penalties.

The Act requires the CSLC to develop and adopt regulations governing ballast water management practices for vessels operating within the "Pacific Coast Region” by January 1, 2005 with the goal of no port-to-port transfers of ballast water (M. Falkner, pers. com., 06/29/04). Vessels must comply with the regulations by July 1, 2005. The "Pacific Coast Region” is defined as, all coastal waters on the Pacific Coast of North America east of $154^{\circ} \mathrm{W}$ Longitude and north of $25^{\circ} \mathrm{N}$ Latitude, exclusive of the Gulf of California (PRC Section 71200(j)). “Coastal waters” are defined as estuarine and ocean waters within 200 NM of land (PRC, Section 71200(d)).

The CSLC invited regulators, scientists, environmentalists, and industry representatives to a meeting in May, 2004 to help develop the coastal ballast water regulatory program that 
would meet the requirements of California law and that would be applicable more broadly to the West Coast region. Participants supported a regionally consistent set of regulations. The International Maritime Organization's Convention for the Control and Management of Ship's Ballast Water and Sediments, (Convention) (adopted on February 13, 2004), provided a basis for establishing such regulations. The Convention outlined ballast water exchange guidelines for ships to conduct ballast water exchange at least 200 NM from the nearest land and in water at least $2000 \mathrm{~m}$ in depth. In cases where this is not possible the convention requires ships to conduct exchange as far from the nearest land as possible, and in all cases at least 50 NM from land and in water at least $200 \mathrm{~m}$ in depth.

This 50 NM/200m depth became the focus of the meeting. A Canadian representative at the meeting indicated that Canada would adopt the IMO resolution alternative exchange requirement (50 NM) for vessels that cannot comply with the 200 NM requirements. Washington regulations already include a 50 NM designation for ballast water exchange. The 50NM/200m guideline also coincides with recommendations by a panel of physical oceanographers convened by Portland State University and the Pacific States Marine Fisheries Commission (PSMFC) to evaluate the coastal currents on the west coast as they may influence efficacy of ballast water exchange. "Retention zones”, areas off the Washington, Oregon, and California coast where water tends to remain near-shore were identified as areas to avoid ballast water discharge (Barth et al., 2002). The report also identified areas offshore from the continental shelf break as low risk areas. The continental shelf off of Oregon is narrow, roughly corresponding with the $50 \mathrm{NM}$ offshore designation, with a depth of about $200 \mathrm{~m}$.

Tankers typically use shipping lanes greater than 50 NM offshore to limit impacts of oil spills. The 50 NM limit for ballast water exchange in coastal shipping may create a hazard for 
shipping if ships were forced offshore into shipping lanes typically used by tankers. Tanker operators that participated in the California meeting, however, suggested that safety was not a major concern and that they would simply move further offshore to avoid congestion.

Due to public review requirements, the CSLC must submit the rulemaking package to the California Office of Administrative Law (OAL). This is scheduled to happen in the next couple of months (M. Falkner, pers. com., 08/31/04). If approved, these coastal regulations will become effective July 1, 2005.

The CSLC is mandated to develop and implement regulations governing the evaluation and approval of shipboard experimental treatment systems by July 1, 2005, in consultation with the USCG. Additionally, the CSLC, in consultation with the SWRCB, and an advisory panel, shall submit to the legislature and the public, a report that recommends performance standards for the discharge of ballast water. Finally, the CSLC, in consultation with the SWRCB, USCG and TAG, shall prepare a report for the Legislature and the public on other non-ballast water, ship-mediated vectors of ANS introductions. The Act itself has a sunset clause and will be repealed on January 1, 2010 unless there is subsequent action by the Legislature to extend that date. The new law also requires expanded biological surveys of California waters by the California Department of Fish and Game (DFG), to assess the effectiveness of the program.

Wherever possible, the CSLC works with the scientific community, other West Coast state representatives, Federal agencies, and the international maritime community to standardize ballast water management programs. This coordination and standardization has improved support and compliance by the maritime industry, and has enhanced understanding and the development of solutions to ANS introductions (M. Falkner, pers. com., 08/25/04). 


\begin{abstract}
Alaska
Alaska does not have specific ballast water regulations aimed at preventing introduction of ANS. Alaska does have laws that address the control of invasive species, which prohibits people or organizations from transporting, possessing, selling, purchasing, exporting from the state or releasing the following: fish (or any part of fish), game (or any part), marine aquatic plants, and eggs or nests of fish and game (Alaska Statute 46: Water, Air, Energy and Environmental Conservation, Chapter 3: Environmental Conservation). Ballast water regulations are targeted at contaminated, un-segregated ballast water (ballast water carried in empty oil tanks of tankers) (Section 750: Ballast Water Discharge) and are primarily for preventing discharge of oil, rather than preventing discharge of ANS with ballast water.
\end{abstract}

Other potential Alaskan statutes that could address ballast water include: pollution standards for water quality and regulations governing water temperature; criteria for freshwater aquaculture that specify that temperatures not exceed requirements needed to preserve normal species diversity or to prevent appearance of nuisance organisms”; and mixing zone regulations that allow the Department of Fish and Game to reduce in size or deny a mixing zone if the department finds that available evidence reasonably demonstrates that pollutants discharged could result in undesirable or nuisance aquatic life (R. Piorkowski, pers. com., 02/08/04).

\title{
Canada
}

Since the early 1990's, Canada has had voluntary ballast water guidelines for the St. Lawrence Seaway and the Great Lakes. Initial voluntary guidelines were superseded by the current version of TP13617, the Canadian Shipping Act (CSA) of 2001. TP13617 was expanded in anticipation of the IMO resolution A868 (20), and addressed all Canadian waters and ships 
carrying ballast water. As of today, TP13617 is still voluntary, but representatives from Canada at the June 29, 2004 Pacific Ballast Water Group meeting announced the intention to incorporate TP13617 into Canadian Law by making reference to it in a new ballast water regulation following the IMO convention.

Recognizing the differences within Canada’s aquatic ecosystems, national ballast groups were formed consisting of Atlantic, Quebec, Ontario, Pacific and Arctic areas with the intention of implementing guidelines that take into account differences in trade, ship type, geography, and specific nonindigenous species introductions. As a result, vessel masters, owners, and/or operators are governed by the specific regional ballast water management procedures as outlined in Annexes II, III, IV, and V, which correspond to the various regions (P. Lim, pers. com., 06/29/04). The Pacific Ballast Water Working Group was established under the authority of the Pacific Regional Canadian Marine Advisory Council (CMAC) to look at Canadian western interests, which include waters of the US West Coast. U.S. participation in this Work Group has been extensive and vitally important (C. Hansen, pers. com., 08/23/04).

The CMAC recently released for public consultation a Discussion document of a draft of Proposed Regulations and Standard under the CSA of 2001 to replace the existing voluntary ballast water management guidelines for all waters under Canadian jurisdiction. The finalized draft regulation is likely to incorporate all of the elements of IMO Resolution A868(20), much of TP13617 and the specific details of the Regional Working Groups (P. Lim, pers.com., 06/29/04).

Ballast water regulations under the 2001 Guidelines apply to all vessels entering Canadian waters from outside the EEZ (CSA, 2001); however, under the Proposed Regulations and Standard, they apply to all vessels equipped with ballast tanks or systems entering Canadian 
waters from outside the EEZ (CMAC, 2004). Each ship is required to have on board, and implement, a ballast water management plan, that is based on and compliant with, the Model Ballast Water Management Plan developed by the International Chamber of Shipping (CMAC, 2004). A fully completed ballast water report must also be submitted to the appropriate Marine Communication and Traffic Services Centre (MCTSC) or Transport Canada Marine Safety from vessel Masters destined for a Canadian port (CSA, 2001).

Vessels are subject to appropriate regional ballast water regulations found in the regulation Annex (see below). In general, ballast water taken on board vessels outside Canada's EEZ or outside the Great Lakes Basin should not be discharged in Canadian waters unless one of the following operations has been performed:

- If conditions do not allow exchange, an alternative zone may be used based on notification and authorization, and that results in a ballast water salinity rating of no less than 26 parts per thousand (ppt).

- If ballast water exchange has occurred not less than 200 NM from any shore, where water is not less than $2000 \mathrm{~m}$ in depth, it should be performed in such a manner that the salinity is at least $30 \mathrm{ppt}$ unless conditions do not allow.

- For vessels on coastal voyages where their route does not take them into areas where water depths are greater than $2000 \mathrm{~m}$ and is more than $200 \mathrm{NM}$ from shore, the use of an alternative zone mentioned above can be applied.

(Adapted from the CMAC 2004.)

Canada states that ships performing ballast water exchange shall do so with an efficiency of 95 percent volumetric exchange. For vessels using the pumping-through (flow-through) method, this is achieved by pumping through three times the volume of each ballast water tank (CMAC, 2004).

Ballast water can be kept onboard, be discharged at an approved shore facility, or it can be treated with an environmentally sound alternative technology that has been approved by 
Transport Canada Marine Safety. Any alternative must be at least as effective in removing or killing harmful aquatic organisms as the methods listed above (CSA, 2001; CMAC, 2004). Ballast water management encompasses ballast tank sediment disposal guidelines (CSA, 2001; CMAC, 2004). The present guidelines should convert to these regulations by autumn of 2004, after a 90-day wait period (P. Lim, pers. com., 06/29/04).

Regional Annex: Annex IV Ballast Water Procedures for Vessels Proceeding to the West Coast of Canada

Vessel masters, owners and operators are governed by specific regional ballast water management procedures outlined in an Annex. Annex IV covers the ports of Vancouver, Nanaimo and Fraser River; vessels entering these ports are to send ballast water reports to the MCTS via the Regional Marine Information Centre.

Vessels entering these waters could be subject to ballast water inspections. Ballast water discharge will not be permitted if the vessel is unable to supply information requested and then only after ballast water samples are collected and analyzed (CSA, 2001; CMAC, 2004). If the ballast water does not meet test standards, the vessel will be required to leave the port and perform exchange in the outgoing current of the north side of Juan de Fuca Strait, west of Longitude $123^{\circ} 55^{\prime} \mathrm{W}$ in at least $100 \mathrm{~m}$ of water, at the vessel's expense (CSA, 2001; CMAC, 2004).

Vessels arriving from ports in British Columbia, Alaska, or the west coast of the U.S. (north of Cape Blanco) wanting to discharge ballast water are exempted if the water originated from these waters (CSA, 2001; CMAC, 2004). Log entries will be checked to verify where the ballast water originated, but these provisions do not apply to vessels discharging less than 1000 
metric tones but a port representative must be in attendance prior to discharge (CSA, 2001; CMAC, 2004).

The Proposed Regulations for the Annex state that in situations where weather and sea conditions do not allow exchange, ballast water may be exchanged where water depth is in excess of 200 meters and the contour line is outside of the baselines of the territorial sea of Canada. The current guidelines do not include any provisions regarding alternative ballast water treatment methods. However, the Proposed Regulations state that any vessel using an alternative treatment system shall notify the Canadian Coast Guard 96 hours prior to arrival (CMAC, 2004).

Although the Canadian government regulates ships and shipping in Canada, ports can and do implement their own by-laws that go beyond the Federal regulations. The Vancouver Port was one of the first Ports to do this, and addressed their concerns and needs with a by-law that was in force on January 1, 1998. This regulation states that vessels intending to arrive at the Port Vancouver ballasted, are required to carry out mid-ocean ballast water exchange prior to entering Canadian waters (Jordan, 2000). The Proposed Regulations and Regional standards should represent an evolution of that by-law (C. Hansen, pers. com. 09/07/04).

\section{Federal}

Federal legislation regarding invasive species and ballast water management is currently very dynamic. New rules have been published since the 2002 Oregon ballast water report, and several bills have recently been introduced, as NISA of 1996 expired in 2002. Below are an overview of Federal regulations and a brief introduction to some of the new bills being introduced. 


\section{Current Regulations}

The Nonindigenous Aquatic Nuisance Prevention and Control Act (NANPCA) was passed in November of 1990, in an attempt to address the concern of aquatic nuisance species, primarily the Zebra mussel in the Great Lakes (Northeast Midwest Institute [NEMW], 2001). The purposes of NANPCA are to prevent unintentional introduction and spread of nonindigenous species into US waters via ballast water, as well as to coordinate research and prevention control, understand and minimize economic and ecological impacts of aquatic nuisance species (H.R. 5390). NANPCA also gave the USCG regulatory jurisdiction over ballast water management, and directed the USCG to issue voluntary ballast water guidelines for the Great Lakes, which were mandatory in 1993 (58 FR 67632). A similar rule was added in 1994 for parts of the Hudson River (58 FR 67632).

Six year after its passage, it was reauthorized and the National Invasive Species Act (NISA) of 1996 was to address invasive species introductions in all U.S. waters. Finalized in November 2001, NISA directed the USCG to issue ballast water management guidelines applicable to all U.S. waters in an effort to encourage all ships entering U.S. waters from outside the EEZ to exchange their ballast (66 FR 58381). NISA also directed the USCG to report on the effectiveness of NISA in preventing biological introductions via ballast water discharges after six months. The report (signed on June 3, 2002), found that only about 30 percent of the ships complied with the mandatory reporting requirement and concluded that voluntary ballast water management was not effective (USCG, 2001). Therefore, the USCG made the exchange guidelines mandatory (see below).

On June 14, 2004 the USCG published regulations establishing mandatory reporting for coastal vessels as well as penalties for ships entering a U.S. port that do not submit the ballast 
water management forms 24 hours prior to arriving in port; and established penalties for those vessels bound for the Great Lakes and Hudson River that violate ballast water management requirements; as well as broadened the reporting and record keeping requirements. These penalties are found in subparts C and D of 33 CFR Part 151. Violators of either the mandatory reporting and record keeping regulations or the mandatory management requirements (vessels bound for the Great Lakes or portions of the Hudson River) would be liable for a civil fine of up to $\$ 27,500$ per violation (Patnaik, 2004). Vessels must submit ballast water reports to the NBIC at least 24 hours in advance of arrival to a U.S. port or place of destination. If a vessel's voyage is less than 24 hours, the report must be sent prior to departing the port or place of departure (69 FR 113). If a vessel travels within one COTP zone and does not mix the ballast water with waters outside the same COTP zone, then that vessel is exempted from the reporting requirements (69 FR 113). This rule was effective August 13, 2004. "Port or place of departure” means any port or place in which the vessel is anchored or moored, and "port or place of destination” means any port or place where the vessel is intending to anchor or moor (69 FR 113).

The voluntary ballast water guidelines consisted of:

- $\quad$ best management practices (BMP);

- require the discharge of only the minimal amount of ballast water essential for vessel operations;

- rinsing anchors and anchor chains;

- a ballast water management plan tailored for the vessel, and,

- a proper training of personnel implementing ballast water and sediment management procedures. (Adapted from 33 CFR 151). 
The voluntary guidelines also contain a provision that if a vessel carries ballast water into U.S. waters after operating outside of the EEZ, an exchange should occur from an area no less than 200 NM from any shore, and in water more than 2,000 m deep, or;

- the ballast should be retained on board;

- use an alternative environmentally sound method of ballast water management that has been approved by the USCG before the vessel begins the voyage;

- discharge the water to an approved reception facility; or,

- under extraordinary conditions, conduct a ballast water exchange within an area agreed to by the Captain of the Port (COTP) at the time of request (33 CFR 151).

The USCG currently recognizes that there are two methods of conducting an exchange: 1) an "empty/refill exchange, where the tank or pair of tanks is pumped down to the point where the pumps lose suction, and then is pumped back to the original level; and 2) a "flow-through" method where three volumes of mid-ocean water is pumped into a full tank while the existing coastal or fresh water is pumped or pushed out through another opening (69 FR 114).

On July 28, 2004, the USCG published a rule for a mandatory ballast water management program for U.S. waters, (69 FR 144). The mandatory program requires all vessels equipped with ballast water tanks entering U.S. waters after operating outside of the EEZ to employ one of the following ballast water management procedures:

- Perform ballast water exchange in an area no less than 200 NM offshore.

- Retain ballast on board.

- Use an alternative environmentally sound ballast water management method that has been approved by the USCG (69 FR 144).

The proposed rule changed the mandatory guideline for mid-ocean exchange - the depth requirement $(2,000 \mathrm{~m})$ was deleted from the regulations because there was no consensus on the depth criterion and it simplified enforcement (69 FR 44952). 
In the July 28, 2004 document, it is stated that a vessel is not required to deviate or delay its voyage to comply with the regulation. Vessels not traveling in waters $200 \mathrm{NM}$ or greater from shore from outside the EEZ for a large part of their voyage can retain their ballast on board, or discharge only the amount necessary to ensure the safety of the vessel for cargo operations and upon request make report available to the COTP; however, there are no coastal ballast water management regulations (69 FR 144). This final rule became effective September 27, 2004.

Oregon’s ballast water regulations were created in response to limitations in the national program that failed to be protective of Oregon waters. The new and improved mandatory Federal program increases the level of protection from ANS introduction; however, the federal program still fails to address ballast water management in coastal shipping, which is a major threat to Oregon waters.

In order to comply with NISA, in September 2003, the USCG began to develop objective criteria for ballast water treatment, and published a Notice of Intent that stated that in order to effectively prevent the introductions of aquatic nonindigenous species; a "Standard” for ballast water treatment needs to be based on biological effectiveness. Under NISA, the minimum ballast water discharge standard is stated to be "at least as effective as ballast water exchange” (NISA, 2001). Guiding principals to developing these standards include being scientifically sound, biologically meaningful and enforceable (R. Everett, pers. com., 03/01/04). The USCG offered three alternatives of a ballast water discharge standard (68 FR 187):

- Alternative 1 , is the most stringent, and would result in the discharge of no detectable viable organisms larger than 0.1 microns, and require the removal or inactivation of all membrane-bound organisms, essentially requiring sterilization of the ballast water.

- Alternative 2 would establish maximum discharge concentrations for various types of potential nonindigenous aquatic species, and other microbes. It would result in discharge of no more than a particular number of viable individuals per liter of zooplankton greater than a cut-off size in microns, same for phytoplankton, and discharge of a set of indicator microbes not to exceed a specific concentration. 
- Alternative 3 is a no action alternative, meaning that the primary ballast water management practice would be mid-ocean exchange when safe and feasible. Comments on this were due by December 26, 2003 (Adapted from 68 FR 187).

Ballast discharge standards are to include considerations of; the full range of possible organisms, take into account living organisms versus viable organisms, use indicator microbes as a human health standard and be concentration based (USCG, 2003b).

On August 10, 2004, the U.S. Coast Guard clarified the mandatory reporting for tow vessels and barges. Barges equipped with ballast tanks must submit reports for stops involving cargo operations, and towing vessels with ballast water tanks must submit reports for stops involving fueling operations (Karr, 2004). This clarification of reporting requirements for barges may result in increased reporting to Oregon and will provide a more complete description of barge ballasting operations in Oregon.

\section{$\underline{\text { Proposed Bills }}$}

Increased recognition of the importance of ballast water in dispersal of ANS has stimulated legislation to regulate ballast water management. The National Aquatic Invasive Species Act, (NAISA) of 2003, (S. 525, H.R.1080) was proposed and referred to the Senate Environment and Public Works Committee on March 5, 2003. A subsection of S. 525, specific to research, was subsequently removed and submitted as a separate bill, the Aquatic Species Research Act (H.R. 1081). As a result, S.525 was rewritten and introduced in the House as two separate bills - HR 1080 and HR 1081. These bills are designed to minimize the introduction and transfer of invasive species on a whole ship basis. Some highlights are described below.

NAISA of 2003 would require vessels to have in place an Aquatic Species Management Plan, which would establish interim standards for acceptable operational performance for: ballast 
water exchange, biological effectiveness of ballast water treatment (BWT), and other vessel operations determined to pose a significant risk to the environment through the introduction of ANS. These will be reviewed and be revised as appropriate - but not less than every three years and apply beginning no later than October 1, 2011 (H.R.1080). All ships (transoceanic and coastal) would also be required to install approved ballast treatment technologies if the ship enters service after January 1, 2006 and meet final standards by 2011 unless the ship sails exclusively within a closed system (H.R. 1080). Approved technologies would be allowed for a ten year period, with regular operational checks, and establishing incentives for early installations of approved systems, along with an educational effort geared toward mariners and marine engineers (H.R. 1080). This bill also authorizes funds for research and development of ecological surveys, ballast discharge surveys and treatment technologies, and requires the Department of Defense to develop and implement a towed vessel and structure program to minimize the risk of aquatic species (H.R. 1080).

Senate Bill 2490 (S.2490), titled the Ballast Water Management Act of 2004, was recently brought forth and referred to the Committee on Commerce, Science and Transportation by Senator Inouye and Senator Stevens on June 2, 2004. This bill deals exclusively with ballast water (therefore does not touch on rapid response provisions or early detection) and adopts the IMO framework (A. Cangelosi, pers. com., 07/20/04). It requires vessels to have a ballast water management plan, keep a ballast water record book, outlines ballast water exchange requirements with several exemptions, and establishes standards for ballast water treatment on a schedule.

The ballast water exchange provisions of the bill requires state that until a vessel conducts ballast water treatment in accordance with the bill's regulations, and the operator must 
conducts ballast water exchange with an efficiency of at least 95 percent volumetric exchange, (with special rules for vessels operating in the Great Lakes and areas of the Hudson River) (S. 2490). In general, exchange should occur at least $200 \mathrm{NM}$ from the nearest shore, and in water at least $200 \mathrm{~m}$ in depth. If a vessel is unable to do so, then exchange is to be conducted in water that is as far as possible from land, at least $50 \mathrm{NM}$ and in water of at least $200 \mathrm{~m}$ in depth (S. 2490). A vessel is not required to deviate from its intended voyage or unduly delay it voyage to comply, but should conduct exchange to the maximum extent possible (S.2490).

S. 2490 includes ballast water treatment requirements that are somewhat more stringent than the new IMO Convention treatment requirement and timeline (below), but delays implementation of the final date. This Bill does not include deadlines for rulemaking. Before discharging ballast water in waters of the U.S., S. 2490 requires that a vessel treat the water such that the discharge will contain;

- Less than 0.1 living organisms per cubic meter that are 50 or more micrometers in minimum dimensions;

- Less than 0.1 living organisms per milliliter that are less than 50 micrometers in minimum dimension and more than 10 micrometers in minimum dimension, as well as have concentrations of indicator microbes that are less than;

o 1 colony-forming unit of Toxicogenic vibrio cholera per 100 milliliters or,

o less than 1 colony-forming unit of that microbe per gram of wet weight of zoological samples;

o 126 colony-forming units of Escherichia coli per 100 milliliters; and,

o 33 colony-forming units of intestinal enterococci per 100 milliliters; and,

o concentrations of such indicator microbes as may be specified by the Secretary that are less than the amount specified in the regulations.

(Adapted from S. 2490).

This bill includes a preemption of state law that would affect Oregon regulations. It states that the provisions in the ballast water exchange and the ballast water treatment requirement 
section of the bill supersede any provision of State or local law determined by the Secretary to be inconsistent or to conflict with the requirements of that subsection (S. 2490). Oregon's current ballast water regulations would be consistent with the 200 NM exchange requirement noted above, but does not allow an exemption for vessels because exchange would delay the voyage or cause a vessel to deviate from its track. The Committee on Commerce staff stated that no action will take place on this legislation until 2005 (A. Cangelosi, pers. com., 07/20/04).

H.R. 1081 is a bill to establish research, development and demonstration programs to support efforts to prevent, control and eradicate invasive species. It also includes an education component (H.R. 1081). The bill requires establishing protocols for ecological surveys of nonnative aquatic species that will result in a standardized approach for classifying species, and surveys to collect baseline information on native, nonnative and cryptogenic species, pathways of entry, quantities of organisms being introduced, and practices that lead to introductions. A competitive grants program is also included in this bill for ship pathway surveys, national pathway and ecological survey database, invasion analysis, technology development, demonstration and verification as well as ship pathway demonstration. Furthermore, H.R. 1081 directs the development of a coordinated research program to support the promulgation and implementation of standards to prevent the introduction and spread of invasive species (H.R. 1081).

The Environment and Public Works Committee (EPW) has circulated a bill that is similar to S. 525. The bill includes screening and rapid response, as well as deadlines and standards patterned on the IMO convention (A. Cangelosi, pers. com., 07/20/04). The EPW committee has indicated an intention of moving this bill out of committee and to the Senate this year which is a possibility though not likely (A. Cangelosi, pers. com., 07/20/04). The Transportation and 
Infrastructure Committee (T \& I) may also introduce a ballast water bill similar to S. 2490 with similar deadlines and standards as the IMO convention (see below). Again, the bill is not likely to move until 2005 (A. Cangelosi, pers. com., 07/20/04).

In summary, the current federal ballast water regulations require mandatory ballast water reporting at least 24 hours prior to arriving in a U.S. port, with some exceptions if it is a short voyage. As of September 27, 2004, regulations require vessels to perform ballast water exchange at least 200 NM from shore, use a ballast water treatment method approved by the USCG, or retain the ballast on board. If an exchange cannot be done, because of safety reasons or if it requires delay or deviation from the vessel's course, only the amount of ballast water necessary for safety during cargo operations can be discharged.

Legislative activity on ballast water management in Congress is high. Several bills have been introduced, or may soon be introduced, in Congress (Table 3). It is difficult to predict the direction of future regulation (R. Everett, pers. com., 08/20/04). A bill that mimics ballast water regulations in the IMO Convention- and a research bill (H.R. 1081) are most likely (Cangelosi, 2004). A bill with provisions that differ from those in the IMO convention and more comprehensive legislation on invasive species is also possible, but unlikely (Cangelosi, 2004). 
Table 3. Timeline for current and proposed ballast water discharge and treatment standards.

\begin{tabular}{|c|c|c|c|c|}
\hline & $\begin{array}{c}\text { Current } \\
\text { Regulations } \\
\text { NISA } 2003\end{array}$ & $\begin{array}{c}\text { NAISA } 2003 \\
\text { HB } 1080\end{array}$ & S. 2490 & IMO \\
\hline $\begin{array}{l}\text { Ballast Water } \\
\text { Treatment }\end{array}$ & $\begin{array}{l}\text { Ballast water } \\
\text { exchange: 95\% } \\
\text { open-ocean } \\
\text { volumetric } \\
\text { exchange }\end{array}$ & $\begin{array}{l}\text { Interim BWE: } \\
\text { minimum 95\% } \\
\text { open-ocean } \\
\text { volumetric } \\
\text { exchange, (after } 18 \\
\text { mo. of prom) can } \\
\text { apply until 2011 } \\
\text { Interim BWT: 95\% } \\
\text { removal of aquatic } \\
\text { verts., inverts., } \\
\text { phyoto macroalgae. }\end{array}$ & $\begin{array}{l}\text { BWT: }<0.1 \text { orgs per } \mathrm{m}^{3} \text {, } \\
\text { that are }>50 \text { micometers } \\
\text { in min. dimension } \\
<0.1 \text { orgs. Per milliliter } \\
\text { that are }>50 \text { micrometers } \\
\text { in dimension \& more } \\
\text { than } 10 \text { micrometers } \\
\text { Preemption of state law }\end{array}$ & $\begin{array}{l}\text { BWE: 95\% vol. exchange, at least } 200 \\
\text { NM from nearest land, in water at least } \\
200 \mathrm{~m} \text { in depth, taking into account } \\
\text {--in cases where the ship is unable to } \\
\text { conduct BWE as above, this should be as } \\
\text { far from the land as possible, and in all } \\
\text { cases at least } 50 \text { NM from the nearest } \\
\text { land and in water at least } 200 \text { m in depth. }\end{array}$ \\
\hline Treatment Standards & & $\begin{array}{l}\text { After Interim } \\
\text { established, ships } \\
\text { have } 4 \text { years to } \\
\text { develop final } \\
\text { standards. }\end{array}$ & $\begin{array}{l}\text { As well as have [ ] of } \\
\text { indicator microbes less } \\
\text { than: } \\
--1 \text { colony-forming unit } \\
\text { of Toxicogenic vibrio } \\
\text { cholera } 100 \mathrm{ml} \\
--1 \text { colony-forming unit } \\
\text { of that microbe/g of wet } \\
\text { wt } \\
--126 \text { colony-forming } \\
\text { units of } E \text {. coli / } 100 \mathrm{ml} \text {; } \\
--33 \text { colony-forming } \\
\text { units of intestinal } \\
\text { enterococci/ } 100 \mathrm{ml} \text {; } \\
\text { and, } \\
\text {--[ ] f such indicator } \\
\text { microbes as specified by } \\
\text { Sec. that are < than the } \\
\text { amt specified } \\
\text { Preemption of state law }\end{array}$ & $\begin{array}{l}\text {--Ships conducting BWE” discharge }>10 \\
\text { viable organisms/m }{ }^{3} \text {, greater than or } \\
\text { equal to } 50 \text { micrometers in min. dimen. } \\
\text { and > than } 10 \text { viable organisms/ml less } \\
\text { than } 50 \text { micrometers in min. dim. and } \\
\text { greater than or equal to } 10 \text { micrometers } \\
\text { in min. dimension; and discharge of } \\
\text { indicator microbes will not exceed } \\
\text { specified [ ]. } \\
\text {--Indicator microbes, are but not be } \\
\text { limited to: } \\
\text {--Vibrio cholerae w/ than } 1 \text { colony } \\
\text { forming unit (cfu) } / 100 \text { ml or }<1 \mathrm{cfu} / \mathrm{g} \\
\text { (wet weight) zooplankton } \\
\text {--Escherichia coli less than } 250 \mathrm{cfu} \text { per } \\
100 \text { ml; } \\
\text {--Intestinal Enterococci }<100 \mathrm{cfu} / 100 \\
\mathrm{ml}\end{array}$ \\
\hline Timeline & & $\begin{array}{l}\text { Ships entering } \\
\text { service after Jan 1, } \\
2006 \text { will have to } \\
\text { install approved } \\
\text { treatment } \\
\text { technologies. }\end{array}$ & $\begin{array}{l}\text {--Ships entering service } \\
\text { after } 1 / 1 / 08 \mathrm{w} / \mathrm{BW} \\
<5,000 \mathrm{~m}^{3} \\
\text {--Ships entering service } \\
\text { after } 1 / 1 / 12 \mathrm{w} / \mathrm{BW} \text { of } \\
\geq 5,000 \mathrm{~m}^{3} \\
\text {--For ships constructed } \\
\text { prior to } 1 / 1 / 09 \text {, begin } \\
\text { implement } 1 / 1 / 14 \\
\text { w/BW } 1,500-5,000 \mathrm{~m}^{3} \\
\text {--Ships constructed after } \\
1 / 1 / 09-\text { w/BW } 1,500- \\
5,000 \mathrm{~m}^{3} \text { implement on } \\
1 / 116 \text {, } \\
\text {--Ships constructed } \\
\text { btwn } 1 / 1 / 90-1 / 1 / 12 \\
\text { implement on } 1 / 1 / 16\end{array}$ & $\begin{array}{l}\text { Ships constructed: } \\
\text {--before } 2009 \text { w/BW capacity of } 1500- \\
5000 \mathrm{~m}^{3} \text { must conduct BWM that at least } \\
\text { meets BWE stand. or BW performance } \\
\text { standards until 2014, after it shall at least } \\
\text { meet the BW performance standard } \\
\text {-- in or after } 2009 \text { w/BW capacity of } \\
<5000 \mathrm{~m}^{3} \text { must conduct BWM that meets } \\
\text { BW performance standard } \\
\text {-- in or after } 2009 \text { but before } 2012 \text {, } \\
\text { w/BW capacity of } 5000 \mathrm{~m}^{3} \text { or more shall } \\
\text { conduct BWM that at least meets the } \\
\text { standard described in regulation until } \\
2016 \text { and at least the BW performance } \\
\text { standard after 2016 } \\
\text {--in or after 2012, w/BW capacity of } \\
5000 \mathrm{~m}^{3} \text { or more shall conduct BWM } \\
\text { that at least meets the BW test }\end{array}$ \\
\hline
\end{tabular}

\section{International}

The International Maritime Organization (IMO) is a United Nations specialized agency

concerned with maritime affairs, consisting of 163 Member States, with 32 Member

Governments, acting as the governing body. The objective of the IMO is to facilitate

cooperation among governments and with legal matters involving shipping. The IMO is also 
involved in maritime safety and with marine environment issues involving shipping such as biological invasions due to ballast water discharge, which in September 1995; the IMO identified as a major issue confronting the international maritime community and issued voluntary guidelines entitled, International Guidelines for Preventing the Introduction of Unwanted Aquatic Organisms and Pathogens from Ships' Ballast Water and Sediment Discharges.

In February 2004, the IMO convened a conference to finalize and adopt an international convention for management of ships’ ballast water and sediments. There were representatives of 74 States, one associate member, 18 non-governmental organizations and 2 intergovernmental organizations present (International Conference on Ballast Water Management for Ships Agenda Item 8, 2004). The convention, The International Convention for the Control and Management of Ships Ballast Water and Sediments (Convention) was adopted by consensus at the conference on February 13, 2004 (GloBallast, 2004). The Convention will enter into force 12 months after ratification by 30 states that represent 35 percent of the world's commercial shipping tonnage (GloBallast, 2004). The U.S. has not yet ratified this Convention (R. Everett, pers. com., 03/01/04) however; recently introduced legislation in Congress mimics many of the provisions of the Convention.

The Convention (if ratified) will require all ships to implement a ballast water and sediment management plan, and to maintain a record of ballast water management. Specific regulations for ballast water management are found under Regulation B-3, Ballast Water Management for Ships. The Global Ballast Water Management Programme (GloBallast) website contains a summary of the convention and describes the following regulations and timelines:

- Ships constructed before 2009 with ballast water capacity between 1500 and 5000 cubic meters must conduct ballast water management that at least meets the ballast water exchange standards or ballast water performance standards until 2014, after which time it must at least meet the ballast water performance standard. 
- Ships constructed before 2009 with ballast water capacity of less than 1500 or greater than 5000 cubic meters must conduct ballast water management that at least meets the ballast water exchange standards or the performance standards until 2016, after which time it must at least meet the ballast water performance standard.

- Ships constructed in or after 2009 with a ballast water capacity of less than 5000 cubic meters must conduct ballast water management that at least meets the ballast water performance standard.

- Ships constructed in or after 2009, but before 2012, with a ballast water capacity of 5000 cubic meters or more shall conduct ballast water management that at least meets the ballast water performance standard.

- Ships constructed in or after 2012, with a ballast water capacity of 5000 cubic meters or more shall conduct ballast water management that at least meets the ballast water performance standard.

The Convention acknowledges that there could be alternatives to ballast exchange and that port states may implement treatment performance standards more rigorous than those in the Convention. Alternative to ballast water exchange must be approved by the IMO’s Marine Environmental Protection Committee (MEPC) (GloBallast, Date accessed March 26, 2004).

Regulation B-4 of the Convention stipulates that exchange should, when possible, be performed at least $200 \mathrm{NM}$ from the nearest land and in water at least $200 \mathrm{~m}$ deep. When this is not possible, exchange should occur as far from land as possible, and in all cases at least $50 \mathrm{NM}$ from the nearest land and in water at least $200 \mathrm{~m}$ in depth (GloBallast, 2004).

Regulation D-1 provides ballast water exchange standards. Exchange must be done in open-ocean as far from shore as possible with a minimum efficiency equivalent to 95 percent volumetric exchange (GloBallast, 2004). This can be accomplished by the flow-through method by pumping through three times the volume of each ballast tank. Less than three volumes can be pumped through, provided that the lower volume meets the requirement for at least the 95 percent volumetric exchange (GloBallast, 2004). The empty/refill process can be used if all 
ballast water is discharged until suction is lost and then tanks refilled. Ballast exchange procedures approved by the port State can be used in designated areas as well (GloBallast, 2004).

Regulation D-2 is a ballast water performance standard regulation. It states that ships conducting ballast water management ships shall:

- discharge less than 10 viable organisms per cubic meter greater than or equal to 50 micrometers in minimum dimension and less than 10 viable organisms per milliliter less than 50 micrometers in minimum dimension and greater than or equal to 10 micrometers in minimum dimension.

- The discharge of indicator microbes (including but not limited to: Toxicogenic: Vibrio cholerae, Escherichia coli, intestinal Enterococci) should not exceed the specified concentrations (GloBallast, 2004).

o Toxicogenic: Vibrio cholerae should not exceed concentration of 1 colony forming unit (cfu) per 100 mililiters or less than 1cfu per 1 gram of zooplankton samples.

o Escherichia coli should be at concentrations less than 250 cfu per 100 mililiters, and;

o Intestinal Enterococci should be at concentrations less than $100 \mathrm{cfu}$ per 100 mililiters (GloBallast, 2004).

Regulation D-3 addresses ballast water management/treatment systems. D-3 requires approval by the IMO Administration in accordance with IMO guidelines prior to using a treatment system (IMO, 2004). The Convention gives ships participating in a program to test and evaluate treatment technologies approved by the IMO Administration, a grace period of five years before they must comply with the requirements (GloBallast, 2004).

The Convention also states that parties are allowed to individually or jointly enact more stringent measures to prevent the spread of ANS through discharge of ships' ballast water and sediments. 
The U.S. has not signed on to this Convention and it is unclear when or if that will happen. The Convention is being used, however, as a basis for legislation at the state and federal levels and in Canada, and may provide a framework for consistency at various regulatory scales.

\section{Research}

Preventing the transfer of ANS worldwide is the driving force behind invasion science, policy and management research (Ruiz \& Carlton, 2003). Research is underway on many different pathways of introduction, including: ballast water, (Gollasch et al., 2002), hull fouling (Minchen \& Gollasch, 2003), aquaculture (Williams, 2003), biocontrol and ornamental (Ruiz et al., 2000), and plastic debris (Barnes, 2002). Ballast water is recognized as a primary vector of ANS (Carlton \& Geller 1993; Fig. 2), and therefore ballast water management has received most legislative and scientific attention. Research related to ballast water and invasions can be broadly divided into three areas: 1) biology of ballast water communities and the ecology of invasions, 2) ballast water exchange and the development of treatment technology, 3) ballast water management (which incorporates actions on the previous two).

\section{Biology of Ballast Water Communities and the Ecology of Invasions}

Characterizing the biological communities and physio-chemical properties of ballast water is fundamental to understanding its potential as a vector. Ongoing work in Oregon and on the west coast has four main components:

- Surveying ballast water communities carried from source ports to estimate the potential release of those target organisms into receiving ports.

- Evaluating physio-chemical properties including salinity, temperature, conductivity and chemical composition of the water.

- Assessing survivorship of target organisms under various ballast water exchange scenarios and subsequent discharge conditions. 
- Studying the behavior and ecology of ANS to evaluate the probability transport and establishment in receiving ports.

Research on biology of ballast water and ecology of invasions is being carried out at a variety of scales, from small-scale laboratory investigations to shipboard experiments.

Laboratory experiments provide good survival estimates for specific species that are impossible to study in detail aboard a ship (i.e. separating causation from correlation), but simulation of the real conditions of a ballast tank is difficult to achieve in the laboratory. Therefore, experiments are conducted to assess the probability that ANS will be taken onboard with ballast water and whether the organisms can survive ballast water transport and release into receiver ports. The probability of uptake is examined in the laboratory and field by studying the behavior of larvae and their distribution in the water column. Survivorship during transport, discharge and under various ballast water exchange conditions is simulated using rapid changes in salinity (laboratory) and through repeat sampling of ballast communities on ships.

Studies of transferring pathogens and microbes, which have implications for human health, are becoming an increasingly important topic in invasion research (Bai et al., 2003; Mack et al., 2000). Currently there is little understanding of the risk to human health of viruses and bacteria being transported worldwide. The objective of ballast water - microbe studies is to close the gap in knowledge about the type, amount, and condition of microbes in ballast water in ships. Microbes are the most abundant organisms in the aquatic system and this is likely to be reflected in ballast water communities, yet there has been little research on this topic (Ruiz et al., 2000). To remedy this, data is being collected on the detection, taxonomy, and biology of key pathogenic organisms (e.g., viruses, bacteria [Vibrio cholerae], and protists). This research builds on previous work that suggested ballast water transfer might play an important role in the distribution of microorganisms and epidemiology of some waterborne diseases (Ruiz et al., 
2000). One group has been looking at the use and feasibility of a physical method, in which electrons are accelerated causing the gas molecules to become excited. With this method a strong electric field is produced, creating high concentrations of dissolved hydroxyl radicals with the salt water that then affects the organisms in the ballast water in several ways (Bai et al., 2003). Initial results suggest this could be a low cost ballast water treatment method with a high (99 percent) bacterial kill efficiency, however, further studies are needed (Bai et al., 2003).

In addition to vector science, there is also research into establishment and impacts of ANS. These studies involve:

- Temporal and spatial patterns of ANS populations (e.g. natural expansion, secondary invasion).

- Reproductive, competitive, parasitic, and predator-prey biology of invaders.

- The impacts of invaders on native populations, biodiversity and ecosystem processes.

- The 'invasibility' of native communities and ecosystems (i.e. measuring resistance and resilience of natural systems to invasion events).

- The effects of anthropogenic and climate change on invaders and invasion potential (Stachowicz et al., 2002).

- The purpose of these research efforts is to determine the physiological and ecological parameters that determine invaders' success in becoming established which may lead to effective counter-measures in their control and/or eradication.

\section{Ballast Water Exchange and Development of Treatment Technology}

Ballast water exchange is the most widely applicable and effective method of ballast water management for ANS prevention currently available, however, its efficacy remains uncertain (International Association for Great Lakes Research, 2002; USCG, 2003b). Several problems with the method have led to research into alternative treatments. Barriers to developing and furthering ballast water treatment technology include the lack of:

- performance standards that have international agreement; 
- a protocol for testing and evaluation performance (this applies internationally, however the USCG does have a program (STEP) in place which is discussed below), and;

- communication between the R\&D community, governments, and ship designers, builders and owners.

Technical barriers to developing and furthering ballast water treatment technology also exist on board ships, including:

- pumping capacity for dealing with the huge quantities of ballast water that must be treated (e.g. about 60,000 tons of ballast water on a 200,000 DWT bulk carrier);

- $\quad$ power requirements;

- $\quad$ crew and ship safety; and

- equipment design limitations that result in malfunction in the harsh environment (vibration, high humidity, and corrosion).

Treating ballast water during a voyage prior to discharge is being researched to address the problem of viable organisms reaching receiver ports. Currently the scope of this research is based on three broad methods.

\section{Mechanical treatment}

The mechanical treatment of ballast water involves the use of any mechanisms, such as filters and cavitation, to reduce or prevent ballast water biota entering recipient ports.

Mechanical treatment is not considered a stand-alone ballast water treatment system, but used in concert with another form of treatment such as a chemical treatment. Filtration systems are used at point of entry into the tank, in another phase of the treatment, at the discharge site or in a combination of those areas used to stop the flow of biota into or out of the tank. One such study in Florida is looking at the removal of phytoplankton using a self cleaning $50 \mu \mathrm{m}$ screen and UV treatment (Waite et al., 2003). The screen appeared to remove most of the zooplankton, and a small percentage of micro phytoplankton, and while initial results of the UV treatment demonstrated reduced numbers of microorganisms to an undetectable level, bacterial re-growth 
was observed (Waite et al., 2003). More research and development is needed. Much of this type of technology is being borrowed from wastewater treatment plants.

\section{$\underline{\text { Physical treatment }}$}

Treating the physical properties of ballast water is achieved through manipulating properties such as temperature, UV light exposure and oxygen concentration beyond the lethal tolerance of planktonic biota (Stedman, 2004; Bai et al., 2003). There may be added value in some of these methods such as deoxygenation, which evidence suggests can perform the dual role of reducing ships' corrosion along with preventing viable organisms from invading ports (Tamburri et al., 2002).

\section{$\underline{\text { Chemical treatment }}$}

Adding oxidizers, ozone, toxins and other chemicals has proved effective in rendering inactive potential ballast water invaders. Environmental soundness is a major factor in this research as it is undesirable to impact the environment to a greater extent than already exists with introductions.

\section{Ballast Water Management}

Ballast water management is critical to reducing the risk of invasion and incorporates knowledge gained from the research of ballast water biology and treatment mentioned above. This is done through monitoring of compliance through verification of exchange, consistent monitoring of shipping and ballast water movements via ballast water reporting forms, and implementing enforcement actions.

Currently, salinity measurements are used to verify that ships have complied with the exchange requirement. This is achieved simply by determining if the ballast water is euryhaline 
(open-ocean) or mesohaline (coastal/estuarine). The method is quick and inexpensive; however, minor differences between high-salinity port water and mid-ocean water limit the efficacy.

There are other methods being investigated to verify exchange. Tracers that vary between the open-ocean and coastal environments such as chemicals, radium and metals may be useful in determining the source of the ballast water. Biological samples may also be used for establishing the source of ballast water by comparing the ballast water assemblage to baseline open-ocean and coastal assemblages. Clear descriptions of species whose occurrence is either open-ocean or coastal (but not both) and taxonomic expertise is required for this method. The time to process samples and determining the certainty of the source are limit the application of the method.

Tracking ballast water management operations is critical to understanding where and how ANS are transported by ships. Ballast water management forms contain information about the ship, its ballast tanks, and its route. The reports also contain information about the ballast water; its place of origin, the date it was taken onboard, the amount, and the type of management used, (empty-refill or flow-through). Upkeep and examination of submitted forms is being used to inform regulators of ballast water activities employed, the shipping routes, can also reveal areas of greater of occurrence for discharge and uptake, as well as assists in identifying noncompliance.

Ballast water report forms are a means of collecting information on vessel types and their ballast water practices but should not be used as the sole source of information. Data quality on the forms is suspect (Harkless, 2003) and there are obvious problems with form submission as evidenced by the different numbers of report forms collected by WDFW and NBIC. 
Verification of exchange reported on the forms using a suite of methods, as mentioned above, would provide information to support enforcement actions. Ballast water regulations were established to protect aquatic systems, and enforcement is required for success. Lack of effective enforcement was cited as a reason for non-compliance with ballast water regulations by ships’ officers (Harkless, 2003).

\section{Regional Research Initiatives}

\section{California State Lands Commission}

Between August-December 2000, the California State Lands Commission (CSLC) was awarded grants for the NOAA-Sea Grant and Port of Oakland to implement the West Coast Demonstration Project. Two vessels participated in this research project and a report summarizing that work is due in late summer, 2004. The treatment technology evaluated on both vessels was the OptiMar Ballast System designed/installed by OptiMar AS. The treatment system consisted of combined UV/Hydrocyclone components. Significant engineering issues related to the installation and operation of treatment system was encountered on both vessels. However, these issues were ultimately resolved and shipboard efficacy testing was conducted in the fall of 2002 and summer of 2003. Results showed that UV treatment, coupled with 96h ballast tank containment, resulting in live counts of zooplankton $(>73 \mu \mathrm{m})$ that met the ballast water performance standards recently adopted by the IMO. The volumetric mid-ocean exchange efficiencies, also exceeded the newly adopted ballast water exchange standard of $>95 \%$ efficiency.

Finally the California Department of Fish and Game (CDFG) in consultation with the CSLC and the USCG, is assessing the effectiveness of the ballast water controls implemented 
pursuant to the law. This assessment will create and maintain an inventory of location and geographic range of nonindigenous species populations in California’s coastal and estuarine waters. Data to be collected includes, supplementing existing baseline data with information on intertidal and near-shore habitats, and monitoring coastal and estuarine habitats for new introductions of nonindigenous species or spreading of existing populations as seen in comparisons with the baseline data. The CDFG is to prepare a report of the analysis by January 1, 2007, with an update no later than July 1, 2008, and a report to the Legislature on January 1, 2009. This information will inform subsequent studies on; determination of alternative discharge zones, identification of environmentally sensitive areas to be avoided for uptake or discharge of ballast water, the determination of potential risk zones where uptake of ballast water will be prohibited among others (AB 433).

\section{Washington State}

Washington has a process for approval of experimental treatment technologies for testing and evaluation purposes. The program has approved the installation and testing of two types of ballast water treatment technologies; a filtration and UV-light system from Hyde Marine that will be tested on a Princess Cruise Line vessel, and a black and grey water treatment system that uses the treated water for ballast on a Norwegian Cruise Line vessel (S. Smith, pers. com., 08/26/04). These systems are installed and testing is underway.

The University of Washington is involved in Puget Sound ship sampling, efficacy of a prototype shipboard ozone treatment system, and laboratory mesocosm experiments with potential treatment systems (ozone, UV, SeaKleen ${ }^{\circledR}$, and filtration, and chlorination) (R. Herwig, pers. com., 06/29/04). The ozone research includes laboratory and ship-board studies to examine the efficacy injector and diffuser systems. Shipboard research is conducted on the oil tanker S/T 
Tonsina. Problems with maintenance of the ozone generator onboard ship have limited efficacy (R. Herwig, pers. com., 06/29/04). Russ Herwig, at the University of Washington, is investigating the UV light and biocidal disinfection of ballast water as treatment at the U. S. Geological Survey (USGS) Marrowstone Marine Field Station in Norland, Washington. Mesocosm studies were performed with zooplankton and SeaKleen ${ }^{\circledR}$. A rapid decline of zooplankton was seen, resulting in a $100 \%$ kill; no decline of bacteria was reported and phytoplankton results had not been completed (R. Herwig, pers. com., 06/29/04). These results unfortunately also showed SeaKleen ${ }^{\circledR}$ having a longer than expected half-life. More investigation is underway.

\section{Center for Lakes \& Reservoirs at Portland State University}

Research at the CLR focuses on the biology, transport, and establishment of ANS, developing methods to improve ballast water tracking and management information and verification of ballast water exchange. The work at the CLR is done in collaboration with several funding agencies including the USCG, Pacific States Marine Fisheries Commission (PSMFC), CRSOA, EPA, and U.S. Fish and Wildlife Service (USFWS). Work on ballast water management on the Columbia River is coordinated with through the Columbia River Aquatic Nuisance Species Initiative (CRANSI), led by the ports of Astoria and Portland. The CRANSI was stimulated and given impetus by U.S. Senator Ron Wyden.

The National Invasive Species Act of 1996 authorized an ecological survey of ANS in the Columbia River. CRANSI was instrumental in securing USCG funding for the survey in 2001. LCRANS was undertaken to provide comprehensive information about the ANS present in the Lower Columbia River. The results of this two-year investigation will serve as a baseline for evaluating the rate of species introductions to the river, permit measurement of the efficacy of 
ballast water regulations, determine areas that are vulnerable to invasion, and contribute important new information to ongoing regional ANS studies.

The survey found 79 ANS in the Lower Columbia River (Sytsma et al., 2004 unpublished). The majority of these ANS were associated with shipping-related pathways of introduction, particularly after 1950 when the volume of shipping traffic in the Columbia increased. Those species introduced through shipping were predominantly from Asia. An interim report has been produced (Draheim et al., 2003) and the final report is in preparation. Funding was recently received from the USFWS to extend the lower Columbia River Survey to the middle reaches of the Columbia and lower Snake Rivers.

Ballast exchange verification research at the CLR is conducted in collaboration with the Smithsonian Environmental Research Center (SERC) with USCG funding. CLR and SERC are evaluating a suite of physical and chemical characteristics for discriminating between port and mid-ocean water. The project involves ballast tank and ocean water sampling on transoceanic cruises from Asia and Europe to U.S. ports. The change in concentration with distance from shore for the selected characteristics will be examined to evaluate their ability in discriminating between ocean and port water. Preliminary results suggest that colored dissolved organic matter (CDOM) concentration, in combination with salinity, may provide a screening tool for shipboard verification of exchange. Ballast water that fails the salinity and/or CDOM tests would stimulate more intense scrutiny of ballast water logs to verify exchange.

The CLR is also conducting research on the importance of ships' hulls as a vector of fouling assemblages and introduced species, also with USCG funding. The overall objective of 
the project is to quantitatively assess and compare the magnitude of hull fouling among vessels and operating conditions. More specifically, the project will:

- estimate the extent of biofouling on ships’ hulls entering the Columbia River;

- estimate the extent of biofouling on several types of smaller vessels (e.g., tugs, barges, ferries, fishing boats, pleasure craft);

- test for statistical differences among vessels in the extent (percent) and composition of biofouling, and the extent to which such variation is explained by operating characteristics (e.g., vessel speed, hull husbandry, voyage route) and;

- estimate the amount of hull surface area arriving to key U.S. Pacific coast ports as a function of vessel type and operating characteristics, to provide a coarse estimate (when combined with biofouling data) on the scale of biofouling assemblages arriving.

Proposals have been submitted to increase the scope of this research to ports in California and Alaska.

The CLR is also characterizing the biology of ballast water on ships entering the Columbia River and studying the survival of organisms in ballast tanks from high-risk ports (e.g. those in San Francisco Bay area). San Francisco Bay ports are considered high-risk source ports because the area is heavily invaded and the low salinity is similar to that of the Lower Columbia River. Exchanged and unexchanged ballast water in vessels arriving in the Columbia River from San Francisco Bay are sampled using plankton light traps and net tows to evaluate the survival and estimate risk under each management scenario. Funding for this research is from the USCG, the PSMFC, the CRSOA, and the EPA.

Mitten crabs (Eriocheir sinensis) are well established in the San Francisco Bay-Delta system and pose a treat to the Columbia River if introduced. The CLR is conducting research on potential range expansion of mitten crabs. This work focuses on evaluating physical and chemical characteristics of Pacific Northwest estuaries and factors that influence mitten crab 
recruitment (salinity, temperature, larval behavior) to assess the probability of mitten crab transport and establishment.

Tracking ballast water management operations is critical to understanding where and how ANS are transported by ships. The CLR and SERC have initiated a joint project to coordinate the ballast water reporting efforts of the NBIC and the State of Oregon. The goals of the pilot project are to reduce duplicative data entry and processing and to increase the quality of data gathered at both state and federal levels. PSU will act as a liaison between the NBIC, which is located in Maryland, and local agents, agencies, and the Merchants Exchange to follow up on ballast water reports that are missing or erroneous.

The Oregon legislature and the local shipping industry have indicated support for investing federal agencies with regulation of ballast water rather than development of a state program, if the federal program is protective of Oregon water resources. The joint SERC/PSU project melds the strengths of both approaches to create a collaborative program that adds value to both the state and federal efforts. By collaborating with the federal data management program at the NBIC Oregon, and potentially other states, can invest their resources into the important practical and complementary activities of seeking missing forms (i.e., ships which did not submit as required), filling in information gaps in submitted forms, and ground-truthing and correcting errors via follow-up interviews with ships. Ultimately, both state and federal ballast water management programs should benefit from increased data quality and collaboration between federal and state efforts.

SERC/PSU research has led to the formation of a joint effort between the two institutions to form an Aquatic Bioinvasions Research and Policy Program. The program has received 
startup funding from PSU and SERC. The goals of the program are to coordinate work on marine and freshwater aquatic bioinvasion work on the East and West Coast.

\section{NOAA Programs}

The Ballast Water Technology Demonstration Program is a joint NOAA, U.S. Fish and Wildlife Service (USFWS), and U.S. Maritime Administration (MARAD) program initiative. This program will disperse \$2 million for ballast water treatment technology testing for FY 2005. The MARAD program provides vessels for use as test platforms. Technology demonstration proposals must include a long-term plan that outlines how the technology will be developed from its current state into an effective and commercially viable ballast water treatment system, and how the proposed project is an essential part of this development. Matching funds are required.

Recent (2002, no new grants in 2003) ballast water treatment research funded by NOAA includes investigation of:

- methods to minimize ballast water discharge

- deoxygenation treatment

- heat treatment

- improvement in ballast tank design to maximize treatment effectiveness

- risks posed by biocides

- acoustic cavitation treatment, and

- combination of filtration with ozone, and sonic treatments.

In addition, NOAA funds research, outreach and education on ANS through a separate Sea Grant Aquatic Invasive Species Research and Outreach program and recently requests for proposals have been announced for 2004. 


\section{United States Coast Guard Programs}

The United States Coast Guard launched the Shipboard Technology Evaluation Program (STEP) on January 7, 2004. The purpose of STEP is to encourage research and development of effective ballast water treatment systems by providing an incentive for foreign and domestic vessel owners to collaborate on system testing. A ship that installs a system for testing and evaluation that does not meet the final ballast water treatment standard receives an exemption from future requirements to meet ballast water treatment standards for the life of the system or ten years, whichever comes first. (USCG STEP, Date accessed August 30, 2004). Participation in STEP requires well-documented monitoring of the treatment system. Monitoring includes an initial five-year experimental phase and a subsequent monitoring phase. After the first year of the experimental phase, the system must be shown to be operating consistently as a requirement to remain in the program. Annual and quarterly reports are also required during both the experimental and monitoring phases. Presently the USCG has two STEP applications in review. Announcement of when vessels are accepted to the program will be made on the USCG website (K. Moore, pers. com., 08/27/04).

\section{United States Environment Protection Agency Programs}

The U.S. Environmental Protection Agency's (EPA) is working with the USCG on the Environmental Technology Verification (ETV) program to develop a protocol for verification of the performance of ballast water treatment technologies. The projected outcomes or products for this initiative include protocols for testing and verifying ballast water exchange and reporting on treatment technologies (ETV, Date accessed August 5, 2004). These protocols include physical, chemical and biological tests with result thresholds of $10^{2}-10^{3}$ zooplankton per liter, $10^{5}$ protists per liter and $10^{6}$ bacteria per liter. The status of these protocols is pending. 


\section{United States Geological Survey Programs}

For the 2002-2003 funding year, the USGS provided funds for a water resource protection project examining crumb rubber filtration as a ballast water treatment system. This is being carried out in Baltimore and Philadelphia harbors.

The USGS, in conjunction with the University of Washington, is investigating the potential to develop a molecular diagnostic system for ballast water. The research is based on cataloguing the DNA of aquatic organisms, from Puget Sound (range intends to be expanded) so that a system can be devised that invasive species in ballast water could be identified before being discharged (R Rodriquez, pers. com., April 8, 2004).

The USGS and research partners (University of Washington) at the Marrowstone Laboratory, in Washington are investigating the efficacy of UV treatment on ballast water plankton and microbes. Specifically, they are manipulating UV dosages to assess the resilience of specific taxa. In addition to examining the effects of treatments, researchers are attempting to develop new ways of measuring treatment effectiveness using remote sensors, particle counters and genetic markers. Mesocosm investigations are also being conducted here using SeaKleen ${ }^{\circledR}$ (see Research section) (R. Herwig, pers. com., 06/29/04).

\section{Smithsonian Environmental Research Center (SERC)}

The Smithsonian Environmental Research Center (SERC), through its bioinvasions lab, is currently investigating ballast water biota at arrival in U.S. ports, and in the past, has investigated ballast water microbes and ballast water biodynamics among other topics (SERC website, Date accessed July 17, 2004). The objective of the ballast water microbe study was to close the gap in knowledge about the type, amount, and condition of microbes in ballast water in ships entering the Chesapeake Bay. Their ballast water biodynamics project is investigating the effectiveness of 
the two regularly employed methods for ballast water exchange: flow-through and empty-refill. Preliminary indications are that exchange effectiveness depends on the type of exchange performed and that it varies across taxonomic groups (SERC website date accessed August 16, 2004). SERC is also investigating the seasonal availability (presence/absence) and estimates of invasive Chinese mitten crab, European green crab (Carcinus maenus), Harris mud crab (Rhithropanopeus harrisii), as well as invasive mysids and cumaceans, in close proximity to active ports in San Francisco Bay.

\section{GloBallast}

GloBallast is a program that assists developing countries in implementation of effective measures to control the introduction of ANS. It is a joint program of the International Maritime Organization (IMO), Global Environment Facility (GEF), United Nations Development Programme (UNDP), member governments, and the shipping industry. The program is underway at six initial demonstration sites to implement existing IMO guidelines and prepare for the new international regulatory regime (GloBallast, Date accessed August 20, 2004).

The GloBallast program attempts to reduce barriers to development of effective ballast water treatment options by maintenance of a research and development directory and by hosting a biannual symposium. The GloBallast database lists 63 projects (as of May 2003) in 13 countries. Twenty-six projects are listed in the U.S. Systems listed as under investigation include heat treatment, mechanical and hydrocyclonic separation, biocides, cavitation, hydroacoustics, and on-shore treatment (GloBallast, 2003). Many of the listed projects were completed two to three years ago, and as yet, no commercial applications have been developed. 


\section{Aquatic Invasive Species Conference}

The $13^{\text {th }}$ Annual Conference on Aquatic invasive species is being held at the end of the September. This meeting will include some of the more up-to-date and innovative research going on. The agenda for the meeting includes numerous presentations on impacts, management, and policy on ANS. Ballast water-related presentations included: to be added when abstracts are available.

\section{Conclusion and Recommendations}

The commercial shipping industry is an important component of the Oregon economy. A sustainable economy requires effective and efficient management of pathways of invasive species introduction that are associated with shipping. Oregon water resources are at particular risk to invasive species introduction through shipping because of the nature of the industry in the state. Oregon ports are primarily engaged in export of bulk cargo on vessels that enter our ports empty and in-ballast. Furthermore, Oregon ports are often the second port of call for vessels coming to the west coast of the U.S., ports like those in the San Francisco Bay - Delta area that are highly invaded. The short transit time and presence of ANS that are known to survive in ballast water makes ballast water taken onboard in domestic ports a high risk as well for introductions to Oregon waters. An effective ballast water management program is therefore critical to protection of the natural resources of Oregon.

The Oregon Ballast Water Management Program was created in response to the risk of biological invasions through ballast water discharge in the absence of a Federal program. Although federal regulations are improving, the management of ballast water discharge has only been mandatory since September 27, 2004 (Great Lakes and Hudson River have had mandatory 
management since 1993 and 1994 respectively) and transport of organisms in coastal shipping has yet to be effectively addressed.

This report addressed a number of considerations outlined by the legislature in HB 3620 . These considerations are summarized and recommendations are provided below.

\section{Shipping Industry Compliance}

Evaluation of compliance with Oregon law was made using data from the National Ballast Information Clearinghouse (2003 data was available) and WDFW. There was no program in place to monitor compliance in Oregon. The WDFW database was more complete than the NBIC database. The WDFW database contained 38 percent more ballast water forms from ships from outside the EEZ and included data from coastal vessels. According to the WDFW data, reporting compliance was very low for the 2003-2004 year; 60 percent of ships calling on Oregon ports either failed to report (29 percent), submitted incomplete reports (30 percent), or submitted late reports (one percent). Compliance was much lower than the reported compliance of 98.5 percent in 2002. As was noted by Vinograd and Sytsma (2002), compliance is highly correlated with staffing level. In 2002, a graduate student was able to follow up on missing or incomplete forms. Staff time at WDFW prohibited similar follow-up.

The current Oregon ballast water program is unfunded and essentially unmanaged; resulting in ineffective and inefficient monitoring of vessel compliance. The resulting low quality data and low reporting compliance leave Oregon's waters at risk to invasion. Resources dedicated to oversight and enforcement of Oregon ballast water regulations are needed. Staff time is required for follow-up on problem or missing reports, monitoring of reports, and enforcement of regulations. A recent (August 13, 2004) USCG final rule requires all vessels 
(from outside the EEZ and coastal) to report ballast water management to the NBIC and provides for substantial penalties for non-reporting. The penalties, along with a shift to electronic reporting, should help increase reporting compliance. Furthermore, a collaborative project between the CLR at PSU and the SERC should streamline data handling and completeness. Still, enforcement of state law is lacking. A 0.5 FTE position at DEQ for enforcement, and coordination with neighboring states and the PSU/SERC effort, is needed to increase compliance and protect Oregon water resources.

\section{Ballast Water Treatment Technologies and Standards for Ballast Water Discharge}

Ballast water exchange remains the most widely applicable method for reducing the risk of introducing ANS via ballast water discharge. A variety of treatment technologies have been proposed but few are ready for full-scale shipboard testing. Those technologies that have been installed on ships have experienced technical problems related to the harsh environment on board a ship, failed to kill all taxa and/or life-stages of ballast water organisms, or have residual toxicity problems. Research is underway in multiple countries, but has been hampered by the lack of funding and lack of an international standard for discharge.

There are many proposed standards for ballast water discharge. These include one proposed by the USCG in a Programmatic Environmental Impact Statement (PEIS) (USCG, 2003b) that has not been published; another in the IMO Convention that was approved on February 13, 2004, but that not been signed by the U.S; a third in a recent bill NAISA of 2003 (HB 1080), which was introduced into Congress in March 2004 but not yet passed; a fourth in another proposed bill (S. 2490); and an interim standard for the State of Washington (see Table 3). The proposed standards vary and all have different timelines of enforcement. It is difficult to predict what will be adopted internationally and nationally. Oregon should monitor and 
participate in the development of ballast water discharge standards to ensure that the standard that is finally adopted is protective of Oregon resources.

\section{Efficacy of Ballast Water Exchange}

Ballast water exchange reduces risk of introduction; however, the magnitude of risk reduction is not well defined because of inefficiencies related to ballast tank design. Use of exchange for management of ballast water in coastal shipping, particularly when no distance from shore is specified in the requirements, may spread organisms along the coast and facilitate spread of ANS. Oregon should optimize application of exchange for management of ANS in coastal shipping by amending the coastal exchange definition to require exchange at greater than

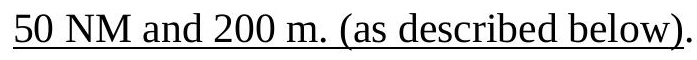

\section{Compatibility with Federal Laws and Regional Programs}

Recent modification of USCG rules on ballast water management on ships from outside the EEZ included removal of the requirement for exchange in water deeper than $2000 \mathrm{~m}$. To maintain compatibility with USCG requirements Oregon law should be amended by deleting the 2000 m requirement for open sea exchange.

Oregon and Washington currently have differing regulation for management of ballast water in coastal vessels. The legislature amended the definition of coastal exchange during the last session to allow discharge of water managed using a regionally or federally approved protocol. A regional protocol for management of ballast water in coastal shipping was proposed at a meeting in California in April 2004. The protocol would require exchange to occur greater than 50 NM from shore and at depths greater than $200 \mathrm{~m}$. If adopted this protocol would be more 
protective and more easily implemented than the current requirements. Oregon law should be amended to eliminate the current latitude definition and to include the 50NM/200m criteria.

The USCG, California, Canada, and proposed IMO Convention all require, or have proposed the requirement, that vessels keep and maintain a ballast water management record log book, and a ballast water management plan specific to each vessel or class of vessels. Oregon law should be amended to include the requirement for a ballast water management log and plan.

Oregon law requires replacement of ballast water through open sea or coastal exchange but methods for replacement are not defined. Definitions of coastal and open-sea exchange in Oregon law should be amended to include the USCG definitions of exchange using flow-through or empty-refill. Such an amendment would prohibit discharge of partially exchanged ballast water.

Oregon ballast water reporting regulations require that a vessel submit a ballast water report at least 24 hours prior to entering waters of the state. Washington also requires reporting 24 hours prior to arrival in their waters, while California requires form submittal upon the vessels departure from each port. Federal ballast water reporting guidelines take into account the varying length of time vessels travel between ports. In order to be consistent with the USCG regulations, Oregon law should be amended to include the USCG language that defines "port or place" and provides reporting instructions for vessels on voyages less than 24 hours in length.

Regional consistency in ballast water management is required for efficient shipping and effective protection against introductions of aquatic organisms. Oregon should continue coordination efforts with other regional regulating bodies regarding ballast water management. 


\section{Research Requirements for Management of ANS Introductions}

Several ongoing research efforts at the CLR address management of ANS in ballast water, however, much additional work is needed to address ANS in ballast water, and invasive species in general. Additional research is needed on rates and pathways of introduction (e.g., the importance of barges), invasibility of various habitats, economic and ecological impacts of ANS, and treatment of ballast water. The joint PSU/SERC Aquatic Bioinvasion Research and Policy Program will assist in answering some important questions related to ANS introduction and impacts, however, a major investment by the State in ballast water management technology $\underline{\text { through establishment of a center of expertise on engineering, economics, ecology, and biology }}$ of ANS management in ballast water and shipping is needed. Such an investment could propel Oregon to the forefront of a newly emerging, "green” industry that is evolving to address this worldwide, multibillion-dollar problem.

\section{Ballast Water Management and Oregon Invasive Species Management}

Management of ballast water is a priority in the Oregon Aquatic Nuisance Species Management Plan (Hanson and Sytsma, 2001). The Center for Lakes and Reservoirs is implementing the Plan in collaboration with state agencies. CLR staff and students working on ballast water issues are unpaid interns at DEQ, and CLR staff and DEQ staff communicate regularly. To the degree that DEQ staffing levels permit, ballast water management in Oregon is well integrated with efforts to manage invasive species in Oregon. Additional resources are required to enhance and improve that integration. 


\section{Other Considerations}

Recent decline in the number of container lines calling on Columbia River ports, suggest that a there will be change in the types of ships calling on Oregon ports in the future. For example, barge shipping may become increasingly important on the Columbia as a link to container shipping in Puget Sound. The U.S. Coast Guard requires articulated tug and barges (ATB) and integrated tug and barges (ITB) to report ballast water management operations and they may be considered self-propelled vessels under Oregon law. Currently unmanned, towed barges are not covered under Oregon ballast water reporting regulations. Further investigation into barge activity, port stops, and routes, as well as outreach and consultation with ocean-going and river barge operators is needed to clarify risk, ballast water management operations, and reporting requirements.

Funding for enforcement of the Oregon ballast water program is required. A 0.5 FTE position to coordinate the DEQ enforcement effort with ongoing programs in California, Washington, and the USCG requires approximately \$60,000 annually. Potential funding sources include; general funds, grant programs, or fees from ships. General fund resources are limited and grant funds are not typically available for ongoing enforcement. The California ballast water program is fee-based and has a high (>90 percent) compliance rate. Approximately 1200 vessel calls are made annually in Oregon, and a per ship fee of approximately \$50 would fund enforcement of ballast water management laws in Oregon. Efforts such as the grant-funded CLR/SERC database project will help support the ballast water program; however State support for enforcement of the law is still needed.

Policy and science on ballast water management and the role of shipping related pathways in dispersal of ANS will continue to evolve at international, federal, and state scales. 
Report on Oregon Ballast Water Management Program 2004

Policy in Oregon must co-evolve to ensure compatibility with new federal and neighboring state legislation and standards. The Ballast Water Task Force should be extended through 2006 and charged with updating the 2007 Legislature on policy and science relating to ANS and shipping. 


\section{References}

AB 433 Assembly Bill No. 433. (Public Resources Code (PRC) §71200 - 71271). http://info.sen.ca.gov/pub/bill/asm/ab_0401-0450/ab_433_bill_20030924_chaptered.pdf. Legislative Counsel of California. State Capitol Building, Room 3021, Sacramento, California (916) 341-8000. http://www.legislativecounsel.ca.gov/Legislative+Counsel/Home/_default.htm. http://www.leginfo.ca.gov/. Date accessed: May 10, 2004.

Alaska Administrative Code 18 (70.0250(b). (18 AAC 70.020b). Alaska Administrative Code: http://www.legis.state.ak.us/cgi-bin/folioisa.dll/aac?. Alaska Legislative home: http://w3.legis.state.ak.us/home.html Last Updated 6/24/04, Date Accessed 07/12/04, http://www.legis.state.ak.us/cgibin/folioisa.dll/stattx00/query=46!2E03!2E750/doc/\{@17696\}?. Date Accessed: 05/10/04.

Alaska Statute 46, Chapter 3, Section 750. Alaska State Legislature. Home website: http://w3.legis.state.ak.us/home.htm?. Juneau Legislative Office, State Capitol, Terry Miller Building, Juneau, Alaska 99801-1182. (907) 465-2864. Statute Retrieval: http://www.legis.state.ak.us/basis/sirs_form.asp?session=23. Last updated 06/29/04.

Bai, M., Zhang, Z., Bai, X., Zhou, X., Deng, S. \& Wang, N. 2003. Tile Killing of microorganisms in ship as ballast water using hydroxyl radicals. Oceanologia et limnologia sinica. 34(5):484-489.

Barnes, D.K.A. 2002. Invasions by marine life on plastic debris. Nature. 416:808-809.

Barth, J., Collins, C., Hickey, B. 2002. West Coast Oceanography: Implications for Ballast Water Exchange. Summary of West Coast Coastal Exchange Workshop, Pacific Ballast Water Group. Eds: McDowell, K. \& Sytsma, M.

California Department of Fish and Game. 2004. Headquarters, 1416 Ninth Street, Sacramento, California 95814. (916) 445-0411.

Canada Shipping Act (CSA) 2001. Tp13617E. Guidelines for the Control of Ballast Water Discharge from Ships in Waters Under Canadian Jurisdiction. Canada Department of Justice, Ottawa, Ontario K1A 0H8, (613) 957-4222. Tp13617E: http://www.transportcanada.org/MarineSafety/Tp/Tp13617/menu.htm. Transport Canada Tower C, Place de Ville, 330 Sparks Street, Ottawa, Ontario K1A 0N5. (613) 990-2309 http://www.transport-canada.org/MarineSafety/Tp/Tp13617/Tp13617Erev1.pdf. Date Accessed: March 10, 2004, August 23, 2004. Last Updated August 9, 2004.

Cangelosi, A. 2004. Status of National Invasive Species Act Reauthorization. Presentation for the Western Regional Panel Annual Meeting. Anchorage, Alaska. September 8-10, 2004. Allegra Cangelosi, Senior Policy Analyst Ecosystems. Northeast Midwest Institute. 218 D St SE, Washington DC, 20003-1900. (202) 544-5200.

Cangelosi, Allegra. 2004. Personal Communication. July 20, 2004. Allegra Cangelosi, Senior Policy Analyst Ecosystems, John Champion, Policy Analyst Ecosystems Northeast Midwest Institute. 218 D St SE, Washington DC, 20003-1900. (202) 544-5200. 
Carlton, J.T. 1996. Marine Bioinvasions: The Alteration of Marine Ecosystems by Nonindigenous Species. Oceanography. 9(1):36-43.

Carlton, J.T. 2001. Introduced Species in U.S. Coastal Waters: Environmental Impacts and Management Priorities. Prepared by Williams College and Mystic Seaport for the Pew Oceans Commission, Arlington, VA. pp. 1-22.

Carlton, J.T. \& Geller, J.B. 1993. Ecological roulette: the global transport of non-indigenous marine organisms. Science. 261:78-82.

Carlton, J.T., Reid, D.M., \& van Leeuwen, H. 1995. Shipping Study. The Role of Shipping in the Introduction of Nonindigeneous Aquatic Organisms to the Coastal Waters of the United States (other than the Great Lakes). National Sea Grant College Program/Connecticut Sea Grant Project R/ES-6, U.S. Coast Guard Research and Development Center, Groton, CT.

Carlton, J. T., Thompson, J.K., Schemel, L.E., \& Nichols, F. H. 1990. Remarkable invasion of San Francisco Bay (California, USA) by the Asian clam Potamocorbula amurensis. I. Introduction and dispersal, Marine Ecology Progress Series. 66: 81-94.

Canada Maritime Administrative Council (CMAC). 2004. National ballast water management regulations under the existing Canada Shipping Act Regulatory reform project - Phase 1. Transport Canada, International and Regulatory Affairs. 330 Sparks Street, Ottawa, Ontario K1A 0N8.

CFR (Code of Federal Regulations). 33 CFR Part 151. Department of Transportation, United States Coast Guard.

Cohen, A.N., \& Carlton, J.T. 1998. Accelerating invasion rate in a highly invaded Estuary. Science. 279:555-558.

Degens, Sebastian. Personal Communication. Marine Planning \& Development Manager Port of Portland, 121 NW Everett Street, Portland, Oregon 97209. (503) 944-7214.

Draheim, R.W., Chapman, J. Cordell, J. \& Sytsma, M. 2003. Interim report: Lower Columbia River aquatic nuisance species survey. www.clr.pdx.edu.

Dukes, J.S. \& Mooney, H.A. 1999. Does global change increase the success of biological invaders? Tree. 14(4) pp. 135-139.

Environmental Technology Verification Program (ETV) Website. Date Accessed 08/05/04. http://www.epa.gov/etv/. Environmental Protection Agency. Last Updated 07/30/04. Environmental Protection Agency, Ariel Rios Building, 1200 Pennsylvania Avenue, N.W., Washington, DC 20460 (202) 272-0167.

Everett, Richard. Personal communication. Environmental Standards Division (G-MSO-4), Aquatic Nuisance Species Program - R \& D Coordinator US Coast Guard. 03/01/04, 08/20/04.

Falkner, M. 2003. Report on the California Ballast Water Management Program. Produced for the California State Legislature. California State Lands Commission, February 2003. Retrieved from: http://www.slc.ca.gov/Division_Pages/MFD/MFD_Programs/Ballast_Water/Documents/ LegRptFull.doc. 
Falkner, M. 2003 Key Components. California State Lands Commission (CSLC). Retrieved from:

http://www.slc.ca.gov/Division_Pages/MFD/MFD_Programs/Ballast_Water/Documents/ KeyCompAB433Rvs.pdf CSLC Home page: www.slc.ca.gov/. 200 Oceangate, Suite 900, Long Beach, California 90802. 916- 574-1800.

Falkner, Maurya. Personal communication. Ballast Water Program Manager, Marine Facilities Division. California State Lands Commission. 08/25/04, 08/31/04, 09/17/04.

Fofonoff, P.W., Ruiz, G.M., Steves, B. \& Carlton, J.T. 2003. In Ships or on Ships? Mechanisms of Transfer and Invasion for Nonnative Species to the Coasts of North America. pp. 152182. In: Invasive Species Vectors and Management Strategies. Eds. Ruiz, G.M. \& Carlton, J.T., Island Press. Washington, D.C.

58 FR 67632. December 30, 1994. 44691-44696.

69 FR 113. June 14, 2004. 32864-32871.

66 FR 58381, November 21, 2001. 58375-58381.

68 FR 187 September 26, 2003. 55463-55645.

68 FR 44692, July 30, 2003. 44691-44696.

69 FR 114. July 28, 2004. 44952-44961.

Fuller, P.L., Nico, L.G., \& Williams, J.D. 1999. Nonindigenous fishes introductions into inland waters in the United States. Washington, D.C.: Environmental Defense Fund.

Global Ballast Water Management Programme (GloBallast). 2003. Ballast Water Treatment R \& D Directory. Programme Coordination Unit. International Maritime Organization. 4 Albert Embankment, London SE1 7SR.

Global Ballast Water Management Programme (GloBallast). http://globallast.imo.org. Office of Ballast Water Management, Marine Environment Division, International Maritime Organization, 4 Albert Embankment, London SE1 7SR, United Kingdom. Date accessed 02/17/04, 03/24/04, 03/26/04, 08/20/04.

Global Ballast Water Management Programme (GloBallast). 2004. Convention adopted by consensus. Ballast Water News. Issue 16:3-4.

Gollasch, S. 2002. The importance of ship hull fouling as a vector of species introductions in the North Sea. Biofouling.18:105-121.

Gollasch, S., Macdonald, E., Belson, S., Botnen, H., Christensen, J.T., Hamer, J.P., Houvenaghel, G., Jelmert, A., Lucas, I., Masson, D., McCollin, T., Olenin, S., Persson, A., Wallentinus, I., Wetsteyn, L.P.M.J., \& Wittling, T. 2002. Life in ballast tanks. pp 217-231. In: Invasive aquatic species of Europe: Distributions, impacts, and management, Eds., E. Leppakoski, S. Gollasch, \& S. Olenin. Dordrecht: Kluwer Academic Publishers.

Hansen, Charles. Personal Communication. Manager, Marine Safety Transport Canada, Vancouver Regional Office 800 Burrard Street, Vancouver British Columbia V6Z 2J8. (250) 363-0394. 08/23/04. 08/24/04, 09/07/04. 
Hanson, E. \& Sytsma, M. 2001. Oregon Aquatic Nuisance Species Management Plan. Center for Lakes and Reservoirs Portland State University

Harkless, K. 2003. How accurate is ballast water reporting? Aquatic Invaders. 14(1):2-6.

H.B. 3620. 2003. $72^{\text {nd }}$ Oregon Legislative Assembly- 2003 Regular Session. http://pub.das.state.or.us/LEG_BILLS/PDFs/EHB3620.pdf. Oregon State Legislature http://www.leg.state.or.us/. 900 Court Street NE, Salem, Oregon 97301. 503-986-1000.

Herwig, Russ. Personal communication. Associate Research Professor, Aquatic \& Fishery Sciences Marine Ballast Water Specialist, University of Washington. 06/29/04.

Hewitt, C.L., Cambell, M.L., Thresher, R.E., Martin, R.B., Boyd, S., Cohen, B.F., Currie, D.R., Goman, M.F., Keough, M.J., Lewis, J.A., Lockett, M.M., Mays, N., McArthur, M.A. O’Hara, T.D., Poore, G.C.B., Ross, D.J., Storey, M.J., Watson, J.E., \& Wilson, R.S. 2004. Introduced and cryptogenic species in Port Philip Bay, Victoria, Australia. Marine Biology. 144:183-202.

H.R. 1080. March 5, 2003. National Aquatic Invasive Species Act of 2003 Introduced in House.

H.R. 5390. November 27, 1990. Aquatic Nuisance Prevention and Control Act of 1990.101st Congress.

H.R. 5396. September 18, 2002. A Bill to amend the Nonindigenous Nuisance Prevention and Control Act of 1990 to reauthorize and improve that Act. House of Representative, 107th Congress, 2D Session.

International Association for Great Lakes Research. 2002. Research and management priorities for aquatic invasive species in the Great Lakes.

International Maritime Organization (IMO) 2004a. International Convention for the Control and Management of Ships' Ballast Water and Sediments. Retrieved from: Home website http://www.imo.org/HOME.html. International Maritime Organization, 4 Albert Embankment, London SE1 7SR, United Kingdom. Date accessed 09/14/04.

Jordan, J. 2000. Press Release. November 2, 2000. http://www.portvancouver.com/contact_us/ Vancouver Port Authority. http://www.portvancouver.com/, 1900-200 Granville Street, Vancouver BC V6C 2P9, Canada. 604.665.9000.

Karr, M. B. Guidance for ballast water regulations. MOC Policy Letter 16450. U.S. Department of Homeland Security. U.S. Coast Guard. August 10, 2004.

Lim, Pat. Personal communication. Fisheries and Oceans. Vancouver, British Columbia, V6C 3S4 (604)-666-0384. 06/29/04.

Mack, R.N., Simberloff, D., Lonsdale, W.M., Evans, H., Clout, M. \& Bazzaz, F.A. 2000. Biotic invasions: cause, epidemiology, global consequences and control. Ecological Applications. 10(3):689-710.

Meacham, Pam. Personal communication. Assistant Invasive Species Coordinator. Washington Department of Fish and Wildlife. 08/25/04.

Minchin, D. \& Gollasch, S. 2003. Fouling and ships' hulls: how changing circumstances and spawning events may result in the spread of exotic species. Biofouling. 19:111-122. 
Moore, Kathy LCDR. Personal communication. Division Chief, Aquatic Nuisance Species (ANS) Program Manager United States Coast Guard. 08/26/04, 08/27/04.

Moore, J.M., Lerner, N., Blanton, N. \& Loe, V. 1998. Breaching Natural Barriers. Bioinvasions. University of Washington.

National Ballast Information Clearinghouse (NBIC). http://invasions.si.edu/nbic/index.html. Date Accessed 08/28/04. Smithsonian Environmental Research Center, 647 Contees Wharf Road, Edgewater, Maryland 21037. (443) 482-2200.

National Invasive Species Act of 1996. Public Law 104-332. http://thomas.loc.gov/cgibin/bdquery/z?d104:HR03217:@@@\&summ2=m\&|TOM:/bss/d104query.html|. Library of Congress: Thomas Legislative Information. http://thomas.loc.gov/home/legbranch/legbranch.html. The Library of Congress, 101 Independence Ave, SE, Washington, DC 20540. (202) 707-5000.

National Invasive Species Act (NISA), 2001. Implementation of the National Invasive Species Act of 1996. 66 FR 225. November 21, 2001. 58381-58393.

National Invasive Species Council. 2001. Management Plan, Meeting the invasive species challenge. Plan prepared under EO 13112, February 1999.

National Research Council (NRC). 1996. Stemming the Tide: Controlling Introductions of Nonindigenous Species by Ship's Ballast Water. U.S. Congress, Office of Technology Assessment, Harmful Non-Indigenous Species in the United States, OTA-F-565 (Washington, DC: U.S. Government Printing Office, September, 1993).

Nehring, S. 2001. After the TBT era: alternative anti-fouling paints and their ecological risks. Senckenbergiana Martima. 31:341-351.

New York Sea Grant. 1994. Nationwide Zebra Mussel Training Initiative Teleconference. December 20, 1994. 1:00 - 4:00 pm. New York Sea Grant Extension Program.

Ohio Sea Grant. 2000. Aquatic Nuisance Species Report: An Update of Sea Grant research and Outreach Projects 2000. http://www.sg.ohio-state.edu/PUBLICATIONS/TB/TB046.htm. Date Accessed: 8/10/04. National Sea Grant, NOAA/Sea Grant, 1315 East-West Highway, SSMC-3, 11th Floor, Silver Springs, Maryland 20910. 301-713-2448. Report prepared by the Ohio Sea Grant College Program. Ed. Karen T. Ricker.

Oregon Blue Book. http://bluebook.state.or.us/facts/economy/economy01.htm, Home page: http://bluebook.state.or.us/. Web Editor: Gary Halvorson. Office of Secretary of State Bill Bradbury. Date Accessed 08/29/04.

Oregon Economic and Community Development Department. 08/26/04 http://www.econ.state.or.us/oregontrade/index.htm. Date Accessed 08/26/04. Home page: http://www.econ.state.or.us/index.htm. State of Oregon, 775 Summer Street, Salem, Oregon 97301. 503-986-0123. Last Updated 02/23/04.

ORS 783. Oregon Revised Statues Chapter 783. http://www.leg.state.or.us/ors/783.html. Oregon State Legislature, 900 Court Street NE, Salem, Oregon 97301 http://www.leg.state.or.us/index.html. http://www.leg.state.or.us/bills_laws/. ORS 725.630, ORS 725.635, ORS 725.640. Date Accessed: 07/29/04. 
Patnaik, B. 2004. Fact Sheet. New ballast water reporting regulations. U.S. Department of Homeland Security. United States Coast Guard. 06/1404.

Pimentel, D., Lach, L., Zuniga, R., \& Morrison, D. 2000. Environmental and economic costs of nonindigenous species in the United States. BioScience 50:53-65.

Piorkowski, Robert. Personal communication. Invasive Species Coordinator Alaska Department Fish and Wildlife. 02/08/04.

Port of Portland (POP). http://www.portofportland.com/AboutPort_Marine.asp. Port of Portland, 121 NW Everett Street, Portland, Oregon 97209-4049. 503-944-7000. Date Accessed 07/29/04. Last Updated: 07/29/04.

Port of Portland (POP). 2004. Strategic Plan, Executive Summary. http://www.portofportland.com/strategic04_05_home.htm. Port of Portland, 121 NW Everett Street, Portland, Oregon 97209-4049. (503) 944-7000. Date Accessed 07/29/04. Last Updated 07/13/04.

Public Resources Code (PRC), Section 71204.5. Legislative Counsel of California. http://info.sen.ca.gov/cgi-bin/displaycode?section=prc\&group=7100172000\&file=71203-71210.5. State Capitol Building, Room 3021, Sacramento, California (916) 341-8000. http://www.legislativecounsel.ca.gov/Legislative+Counsel/Home/_default.htm. http://www.leginfo.ca.gov/. Date Accessed: 07/29/04.

RCW 77.120: Revised Code of Washington, Title 77, Chapter 120. (.005-.040) Washington Legislature.

http://www.leg.wa.gov/RCW/index.cfm?fuseaction=chapterdigest\&chapter=77.120. Washington Legislature home: http://www1.leg.wa.gov/legislature P. O. Box 40551, Olympia, Washington 98504-0551. 360.786.6777. Date Accessed: 07/29/04. RCW 77.120.005: Beginning of Chapter, RCW 77.120.040: Reporting and sampling requirements. RCW 77.120.030: Authorized ballast water discharge.

Reise, K., Gollasch, S., \& Wolff, W.J. 1998. Introduced marine species of the North Sea coasts. Helgolander Meersuntersuchungen. 52:219-234.

Rodriquez, Rusty. Personal communication. Western Fisheries Research Center United State Geological Society. 04/08/04.

Ruiz, G.M. \& Carlton, J. T. 2003. Invasion vectors: A conceptual framework for management. pp. 459-504. In: Invasive Species Vectors and Management Strategies. Eds. Ruiz, G.M. \& Carlton, J.T., Island Press. Washington, D.C

Ruiz, G.M., Miller, A.W., Steves, B. \& Everett, R.A. 2003. Global shipping patterns and marine bioinvasions: the hull story? In review.

Ruiz, G.M., Fofonoff, P.W., Carlton, J.T., Wonham, M.J., \& Hines, A.H. 2000. Invasion of Coastal Marine Communities in North America: Apparent Patterns, Processes, and Biases. Annual Review of Ecological Systems. 31:481-531.

S.2490. http://thomas.loc.gov/cgi-bin/query/z?c108:S.2490.IS. Library of Congress: Thomas Legislative Information http://thomas.loc.gov/home/legbranch/legbranch.html.The 
Library of Congress, 101 Independence Ave, SE, Washington, DC 20540. (202) 7075000. Date Accessed: July 28, 2004. Last Updated: 06/02/04.

S. 525. March 5, 2003. National Aquatic Invasive Species Act of 2003. Introduced.

SB 895. Senate Bill 895. Oregon State Senate Bill, 71st Oregon Legislative Assembly 2001 Regular Session. http://www.leg.state.or.us/01reg/measures/sb0800.dir/sb0895.en.html. Date Accessed 02/20/04.

Smithsonian Environmental Research Center (SERC). http://www.serc.si.edu/. SERC, 647 Contees Wharf Road, Edgewater, Maryland 21037. (443) 482-2200. Date Accessed 07/17/04, 08/16/04.

Simon, K.S. \& Townsend, C.R. (2003). Impacts of freshwater invaders at different levels of ecological organization, with emphasis on salmonids and ecosystem consequences. Freshwater Biology. 48:982-994.

SSB 6329. Substitute Senate Bill. Ballast Water Work Group. Chapter 227, Laws of 2004. 58th Washington Legislature.

Smith, Scott. Personal communication. Invasive Species Coordinator, Washington Department of Fish and Wildlife. 06/29/04, 08/24/04, 08/26/04.

Stachowicz, J.J., Terwin, J.R., Whitlach, R.B., \& Osman, R.W. 2002. Linking climate change and biological invasions: Ocean warming facilitates nonindigenous species invasions. Proceedings of the National Academy of Sciences USA 99: 15497-15500.

Stedman, L. 2004. A unanimous vote of confidence? Water21. 31-32.

Sytsma, M. Unpublished data. Professor Portland State University, Portland, Oregon.

Sytsma, M. 2004. Oregon Invasive Species Action Plan. Oregon Invasive Species Council. March 2004.

Sytsma, M., Chapman, J., Cordell, J. Draheim, R.W. 2004. Lower Columbia River Aquatic Nonindigenous Species Survey. Technical Report. 2001-2003. www.clr.pdx.edu.

Tamburri, M.N., Wasson, K., \& Matsuda, M. 2002. Ballast water deoxygenation can prevent aquatic introductions while reducing ship corrosion. Biological Conservation.103:331341.

United States Coast Guard (USCG). 2001. Report to Congress on the voluntary national guidelines for ballast water management. November 2001. USCG-2002-12147-2.

United States Coast Guard (USCG) 2003a. Programmatic Environmental Assessment for Ballast Water Management Program for U.S. Waters (PEA). Prepared for Commandant, USCG (G-MSR). Submitted by, Battelle, Duxbury, MA. EPA Contract no. 68-C-00-121.

United States Coast Guard (USCG). 2003b. Standards for living organisms in ship’s ballast water discharged in U.S. waters. Department of Homeland Security. U.S. Coast Guard. Federal Register Vol. 68, Number 187.

United States Coast Guard (USCG). 2004. Ballast Water Management Course. USCG home website: www.uscg/USCG.shtm. www.uscg.mil/hq/g-m/mso/mso4/bwmcourse.pdf. Date Accessed 7/10/04. 
United States Coast Guard (USCG). Shipboard Technology Evaluation Program (STEP) website. http://www.uscg.mil/hq/gm/mso/mso4/old/step.htm. Office of Operating and Environmental Standards http://www.uscg.mil/hq/gm/mso/mso4/old/index.htm. Date Accessed 08/30/04.

United States Department of Commerce. (2001). Oregon benefits from exports. http://www.tpa.gov/statetpa/ORtpa.pdf. Home website: http://www.commerce.gov/. U.S. Department of Commerce, International Trade Administration. 1401 Constitution Avenue, NW, Washington, DC 20230.

United State General Accounting Office (U.S. GAO). 2000. Invasive Species: Federal and Selected State Funding to Address Harmful, Nonnative Species. GAO/RCED-00-219.

Vinograd, J. \& Sytsma, M. 2002. Report on the Oregon ballast water management program in 2002. Prepared in cooperation with the Oregon Ballast Water Task Force. December 2002.

WAC 220-77-095, WAC 220-77: Washington Administrative Code, Title 220, Chapter 77 Washington Legislature. http://www.leg.wa.gov/WAC/index.cfm?section=220-77095\&fuseaction=section. Washington Legislature home: http://www1.leg.wa.gov/legislature. P. O. Box 40551, Olympia, Washington 98504-0551. (360) 786-6777. Date Accessed: 07/29/04. Last Updated 08/09/03.

WAC 220.77: Washington Administrative Code, Title 220, Chapter 77. . Washington Legislature home: http://www1.leg.wa.gov/legislature. P. O. Box 40551, Olympia, Washington 98504-0551. (360) 786-6777. Date Accessed: July 29, 2004. Last Updated August 9, 2002.

Waite, T.D., Kazumi, J., Lane, P.V.Z., Farmer, L.L., Smith, S.G., Smith, S.L., Hitchcock, G. \& Capo, T.R. 2003. Removal of natural populations of marine plankton by a large-scale ballast water treatment system. Marine Ecology Progress Series. 258:51-63.

Washington Department of Fish and Wildlife (WDFW). Ballast Water Database. WDFW, Natural Resources Building, 1111 Washington Street, SE , Olympia, Washington 98501. (360) 902-2200.

Wilcove, D.S., Rothstein, D., Dubow, J., Phillips, A., \& Losos, E. 1998. Quantifying threats to imperiled species in the United States. BioScience. 48:607-615.

Williams, S. 2003. Challenges in preventing, eradicating, and controlling invasive seaweeds: the southern California model of Caulerpa taxifolia as a model. Journal of Phycology. 39:(SI):1-63.

Wyatt, B. 2004. Facing the future at the Port of Portland. The Oregonian. August 28, 2004. 


\section{Appendix A. Ballast Water Task Force Advisors, Members and Staff Support}

$\underline{\text { Advisors }}$

Senator Joan Dukes

Representative Wayne Krieger

Members

Mr. Sebastian Degens Port of Portland

Ms. Maurya Falkner California State Lands Commission

Lt. Kelly Gordon USCG Marine Safety Office, Portland

Ms. Cidney Howard Oregon Department of Fish and Wildlife

Mr. Blaine Parker Columbia River Intertribal Fish Commission

Mr. Scott Smith Washington Department of Fish and Wildlife

Mr. Mark Sytsma Portland State University

Captain Jim Townley Columbia River Steamship Operators

Mr. Dick Vander Schaaf The Nature Conservancy

\section{$\underline{\text { Staff Support }}$}

Mr. Jack Wylie

Oregon Department of Environmental Quality

Kiirsten Flynn $\quad$ Portland State University 


\section{Appendix B. Recommended amendments to Oregon Ballast Water Law}

_783.620 Discharge of ballast in navigable waters. Except as provided in ORS 783.635, a person may not discharge the ballast of any vessel into the navigable portions or channels of any of the bays, harbors or rivers of this state, or within the jurisdiction of this state, so as to injuriously affect such portions or channels of such bays, harbors or rivers, or to obstruct navigation thereof. [Formerly 783.600]

783.625 Definitions for ORS 783.625 to 783.640 . As used in ORS 783.625 to 783.640, unless the context requires otherwise:

(1) "Ballast water" means any water used to manipulate the trim and stability of a vessel.

(2) "Cargo vessel" means a self-propelled ship in commerce, other than a tank vessel or a vessel used solely for commercial fish harvesting, of 300 gross tons or more.

(3) "Coastal exchange" means exchange of ballast water, replacing the ballast water taken onboard at a North American coastal port on the west coast of North America south of 40 degrees north latitude or north of 50 degrees north latitude,-more than 50 nautical miles from land and in at least 200 meters (656 feet, 109 fathoms) of waterin one of the following manners:

(a) For vessels departing from a North American coastal port located south of the parallel 40 degrees north latitude and traveling northward into the waters of this state, the replacement of ballast water at sea south of the parallel 40 degrees north latitude;

(b) For vessels departing from a North American coastal port located north of the parallel 50 degrees north latitude and traveling southward into the waters of this state, the replacement of ballast water at sea north of the parallel 50 degrees north latitude; or

(c) In accordance with regional or federal guidelines that provide for methods of replacing ballast water that are equally or more protective of the waters of this state than the methods provided in paragraphs (a) and (b) of this subsection.

(4) "Department" means the Department of Environmental Quality.

(5) "Oil" means oil, gasoline, crude oil, fuel oil, diesel oil, lubricating oil, oil sludge, oil refuse and any other petroleum related product.

(6) "Open sea exchange" means a replacement of ballast water exchange that occurs in an area no less than 200 nautical miles from any shore and where the water depth exceeds 2,000 meters. 
(7) "Passenger vessel" means a ship of 300 gross tons or more carrying passengers for compensation.

(8) "Sediment" means any matter that settles out of ballast water.

(9) "Ship" means any boat, ship, vessel, barge or other floating craft of any kind.

(10) "Tank vessel" means a ship that is constructed or adapted to carry oil in bulk as cargo or cargo residue other than:

(a) A vessel carrying oil in drums, barrels or other packages;

(b) A vessel carrying oil as fuel or stores for that vessel; or

(c) An oil spill response barge or vessel.

(11) "Vessel" means a tank vessel, cargo vessel or passenger vessel.

(12) "Voyage" means any transit by a vessel destined for any Oregon port.

(13) "Waters of this state" means natural waterways including all tidal and nontidal bays, intermittent streams, constantly flowing streams, lakes, wetlands and other bodies of water in this state, navigable and nonnavigable, including that portion of the Pacific Ocean that is in the boundaries of Oregon. [2001 c.722 §1; 2003 c.692 §1]

(14) "Ballast water exchange" means replacement of ballast water in a ballast water tank using empty/refill exchange or flow-through exchange.

(15) "Empty/refill exchange" means the tank (or pair of tanks) is pumped down to the point where the pumps lose suction, and then the tank is pumped back up to the original level.

(16) "Flow-through exchange" means ocean water is pumped into a full tank while the existing port/harbor/fresh water is pumped or pushed through another opening. As defined by the U.S. Coast Guard, a volume equal to three times the ballast tank capacity must be pumped for a flow-through exchange.

(17) "Port or place" means any port or place in which the vessel is anchored or moored.

(18) "Ballast water management plan" means a plan that is specific to each vessel and provides, at a minimum, a description of the ballast water management strategy for the vessel that is sufficiently detailed to allow a master or other appropriate ship's officer or crew member serving on that vessel to understand and follow the ballast water management strategy. 
(19) "Ballast management log" means a description of ballast water management activities, including locations and volumes of ballast water intake and discharge, for each ballast water tank on board the vessel.

783.630 Application; exclusions. (1) This section and ORS 783.635 apply to all vessels carrying ballast water into the waters of this state from a voyage, except a vessel that:

(a) Discharges ballast water only at the location where the ballast water originated, if the ballast water is not mixed with ballast water from areas other than open sea waters;

(b) Does not discharge ballast water in waters of this state;

(c) Traverses only the internal waters of this state;

(d) Traverses only the territorial sea of the United States and does not enter or depart an Oregon port or navigate the waters of this state;

(e) Discharges ballast water that originated solely from waters located between the parallel 40 degrees north latitude and the parallel 50 degrees north latitude; or

(f) Discharges ballast water that has been treated to remove organisms in a manner that is approved by the United States Coast Guard.

(2) ORS 783.630 to 783.640 do not authorize the discharge of oil or noxious liquid substances in a manner prohibited by state, federal or international laws or regulations. Ballast water containing oil or noxious liquid substances shall be discharged in accordance with the applicable requirements.

(3) Nothing in this section:

(a) Requires an open sea exchange or coastal exchange if the owner or operator in charge of a vessel determines that performing an open sea exchange or coastal exchange would threaten the safety or stability of the vessel or the safety of the vessel's crew or passengers because of any extraordinary condition, including but not limited to adverse weather, vessel design limitations or equipment failure.

(b) Exempts the owner or operator in charge of a vessel from the reporting requirements under ORS 783.640, whether or not ballast water is carried or discharged in the waters of this state. [2001 c.722 §2; 2003 c.692 §2]

783.635 Discharge of ballast water prohibited; exemption. (1) Except as authorized by this section, the discharge of ballast water in the waters of this state is prohibited. 
(2) An owner or operator of a vessel may discharge ballast water in the waters of this state:

(a) If the owner or operator has conducted an open sea exchange, or a coastal exchange, if applicable, of ballast water prior to entering the waters of this state; or

(b) Without performing an open sea exchange or a coastal exchange of ballast water if the owner or operator reasonably believes that an exchange would threaten the safety of the vessel or if the exchange is not feasible due to vessel design limitations or equipment failure.

(3) An owner or operator who discharges ballast water in the waters of this state under subsection (2)(b) of this section is subject to the reporting requirements under ORS 783.640. [2001 c.722 §3]

783.640 Reporting of ballast water management.

(1) Owners or operators of vessels regulated under ORS 783.630 to 783.640 must:

(a) -report ballast water management information to the Department of Environmental Quality at least 24 hours prior to-in advance of arrival to a port or place in watersentering the waters of this state. If a vessel's voyage is less than 24 hours the report must be sent prior to departing the port or place of departure. If ballast water management activities differ from that reported, an amended report must be submitted prior to departure. The department may work with maritime associations and the National Ballast Information Clearinghouse to establish the manner and form of such reporting.

(b) -provide access, upon request by the Department of Environmental Quality, for sampling of ballast water tanks, intake, and discharge.

(c) maintain a ballast water management plan that shall, upon request, be made available to the Department of Environmental Quality for inspection and review.

(d) retain for two years a separate ballast water log that shall, upon request, be made available to the Department of Environmental Quality for inspection and review.

(2) The department may verify compliance with ORS 783.630 to 783.640 by relying on tests conducted by the United States Coast Guard or on other tests determined to be appropriate by the department. [2001 c.722 §4]

Note: Sections 3 and 5, chapter 692, Oregon Laws 2003, provide: 
Sec. 3. Task Force on Ballast Water Management. (1)(a) There is created the Task Force on Ballast Water Management.

(b) The President of the Senate and the Speaker of the House of Representatives shall appoint two members from among members of the Legislative Assembly to serve in an advisory capacity to the task force.

(c) The Director of the Department of Environmental Quality may appoint members to the task force who represent federal, state, State of Washington, maritime, environmental and academic interests.

(2) The purpose of the task force is to study and make recommendations on changes and additions to ORS 783.630 to 783.640 , including but not limited to the following considerations:

(a) Shipping industry compliance with ORS 783.630 to 783.640 ;

(b) Practical and cost-effective ballast water treatment technologies;

(c) Appropriate standards for discharge of treated ballast water in waters of this state;

(d) The degree to which open sea exchange and coastal exchange of ballast water decreases the risk of transporting aquatic nonindigenous species into the waters of Oregon;

(e) The compatibility of ORS 783.630 to 783.640 with new laws enacted by the United States Congress, regulations promulgated by the United States Coast Guard and ballast water management programs established by the States of Alaska, California and Washington and the Province of British Columbia;

(f) Research requirements for ballast water treatment technology and other areas of concern related to the possible introduction of aquatic nonindigenous species;

(g) Amendments to the National Invasive Species Act of 1996 (P.L. 104-332) for a single national system of regulation; and

(h) The degree to which ballast water management is consistent with and made a part of efforts to eradicate invasive species throughout Oregon.

(3) The task force is subject to the provisions of ORS 171.605 to 171.635 and has the authority contained in ORS 171.505 and 171.510 .

(4) Portland State University may provide staff support or coordination assistance to the task force, subject to available funding from gifts, grants or donations. 
(5) All agencies of state government, as defined in ORS 174.111, are directed to assist the task force in the performance of its duties and, to the extent permitted by laws relating to confidentiality, to furnish such information and advice as the members of the task force consider necessary to perform their duties.

(6) A majority of the members of the task force constitutes a quorum for the transaction of business.

(7) Official action by the task force requires the approval of a majority of the members of the task force.

(8) The task force shall elect one of its members to serve as chairperson.

(9) The task force shall submit a report, including recommendations for legislation, to an interim committee related to natural resources as appropriate, in the manner provided by ORS 192.245, no later than October 1, $2004 \underline{2006}$.

(10) Notwithstanding ORS 171.072, members of the task force who are members of the Legislative Assembly are not entitled to mileage expenses or a per diem and serve as volunteers on the task force. Other members of the task force are not entitled to compensation or reimbursement for expenses and serve as volunteers on the task force.

(11) As used in this section, "aquatic nonindigenous species" means any species or other viable biological material that enters an ecosystem beyond its historic range. [2003 c.692 §3]

Sec. 5. Section 3 of this 2003 Act is repealed on December 31, 2004. [2003 c.692 $\S 5]$

\section{PENALTIES}

783.990 Penalties. (1) Violation of ORS 783.510 is punishable, upon conviction, in a justice or circuit court, by a fine of not less than $\$ 50$ nor more than $\$ 200$, or by imprisonment in the county jail for not less than one nor more than six months, or both.

(2) Violation of ORS 783.520 is punishable, upon conviction, in a justice or circuit court, by a fine of not less than $\$ 50$ nor more than $\$ 250$, or by imprisonment in the county jail for not less than 60 days nor more than six months. 
(3) Violation of ORS 783.530 is punishable, upon conviction, in a justice or circuit court, by a fine of not less than $\$ 20$ nor more than $\$ 200$, or by imprisonment in the county jail for not less than 10 nor more than 100 days.

(4) Violation of ORS 783.550 is punishable, upon conviction, in a justice or circuit court, by a fine of not less than $\$ 20$ nor more than $\$ 100$ or by imprisonment in the county jail for not less than 10 nor more than 100 days, or both.

(5) Violation of ORS 783.560 by any officer is a Class D violation.

(6) Violation of ORS 783.580 is punishable, upon conviction, by a fine of not less than $\$ 100$ nor more than $\$ 250$, and by imprisonment in the county jail not less than 10 nor more than 25 days. Justices of the peace have jurisdiction of violations of ORS 783.580 .

(7) Violation of ORS 783.590 and injury or damage of any bridge across the Willamette River for want of the appliances described in ORS 783.590 is a Class A violation.

(8) Violation of ORS 783.620 is punishable, upon conviction, by a fine of not less than $\$ 100$ nor more than $\$ 500$, or by imprisonment in the county jail for not less than three months nor more than one year.

(9) Violation of ORS 783.610 is punishable, upon conviction, by a fine of not less than $\$ 100$ nor more than $\$ 200$, or by imprisonment in the county jail not less than one nor more than six months, or both. [Amended by 1953 c.113 §2; 1997 c.249 §224; 1999 c. 1051 §227]

783.992 Civil penalties. (1) Except as provided in subsection (2) of this section, the Director of the Department of Environmental Quality may impose a civil penalty on the owner or operator of a vessel for failure to comply with the requirements of ORS 783.630 to 783.640 . The penalty imposed under this section may not exceed $\$ 5,000$ for each violation. In determining the penalty imposed, the director shall consider whether the violation was intentional, negligent or without any fault and shall consider the quality and nature of risks created by the violation. The owner or operator of a vessel subject to such a penalty may contest the determination by requesting a hearing under ORS 183.413 to 183.470 .

(2) The civil penalty for a violation of the reporting requirements of ORS 783.640 may not exceed $\$ 500$ per violation. [2001 c.722 §7] 
(3) Violation of ORS 783.530 is punishable, upon conviction, in a justice or circuit court, by a fine of not less than $\$ 20$ nor more than $\$ 200$, or by imprisonment in the county jail for not less than 10 nor more than 100 days.

(4) Violation of ORS 783.550 is punishable, upon conviction, in a justice or circuit court, by a fine of not less than $\$ 20$ nor more than $\$ 100$ or by imprisonment in the county jail for not less than 10 nor more than 100 days, or both.

(5) Violation of ORS 783.560 by any officer is a Class D violation.

(6) Violation of ORS 783.580 is punishable, upon conviction, by a fine of not less than $\$ 100$ nor more than $\$ 250$, and by imprisonment in the county jail not less than 10 nor more than 25 days. Justices of the peace have jurisdiction of violations of ORS 783.580 .

(7) Violation of ORS 783.590 and injury or damage of any bridge across the Willamette River for want of the appliances described in ORS 783.590 is a Class A violation.

(8) Violation of ORS 783.620 is punishable, upon conviction, by a fine of not less than $\$ 100$ nor more than $\$ 500$, or by imprisonment in the county jail for not less than three months nor more than one year.

(9) Violation of ORS 783.610 is punishable, upon conviction, by a fine of not less than $\$ 100$ nor more than $\$ 200$, or by imprisonment in the county jail not less than one nor more than six months, or both. [Amended by 1953 c.113 §2; 1997 c.249 §224; 1999 c. 1051 §227]

783.992 Civil penalties. (1) Except as provided in subsection (2) of this section, the Director of the Department of Environmental Quality may impose a civil penalty on the owner or operator of a vessel for failure to comply with the requirements of ORS 783.630 to 783.640 . The penalty imposed under this section may not exceed $\$ 5,000$ for each violation. In determining the penalty imposed, the director shall consider whether the violation was intentional, negligent or without any fault and shall consider the quality and nature of risks created by the violation. The owner or operator of a vessel subject to such a penalty may contest the determination by requesting a hearing under ORS 183.413 to 183.470 .

(2) The civil penalty for a violation of the reporting requirements of ORS 783.640 may not exceed $\$ 500$ per violation. [2001 c.722 §7] 